Inonu University Journal of Art and Design (2021) ISSN: 0000-0000, E-ISSN: 0000-0000

Available online at http://dergipark.gov.tr/iujad

Inonu University Journal of Art and Design

Faculty Homepage: http://www.inonu.edu.tr/tr/gsf

Fotomontaj Tekniğinin 2000'li Yıllarda Türk Resim Sanatına Yansımaları Reflections of Photomontage Technique on Turkish Painting Art in the 2000s Kardelen YAVUZ ${ }^{*} \otimes$ iD, Sezin TÜRK KAYA ${ }^{b} \otimes$

\footnotetext{
${ }^{a}$ Bursa Uludağ Üniversitesi Soyal Bilimler Enstitüsü Resim Anasanat Dalı Yüksek Lisans Mezunu

b Bursa Uludağ Üniversitesi, Güzel Sanatlar Fakültesi , Grafik Tasarımı Bölümü, Görükle, Bursa, 16285, Türkiye
}

Article history: Received 05.09.2021 / Accepted 24.12.2021

\title{
ÖZET ABSTRACT
}

En az iki ayrı fotoğrafın yeni bir düzen bağıntıs oluşturmaksızın süperpoze edilmesiyle oluşturulmuş kompozisyon olan fotomontaj, Dada'dan Pop Sanat'a pek çok Batı Sanat Akımında uygulanmış bir tekniktir. Fotomontaj, fotoğrafta deneysel yaklaşımların ağırlık kazandığı 1980'li yıllarda Türk sanatında da uygulama alanı bulmuş ve günümüzde sayısal ortamın sağladığı olanaklarla birlikte varlığını devam ettirmiştir.

Calışmanın amacı; Fotomontaj tekniğinin tarihsel sürec içinde yeri ve uygulama şekillerinden yola çıkarak, 2000'l yıllarda Türkiye'de fotomontaj tekniğiyle eserler üreten sanatçıları ve fotomontaj tekniğinin Türk resim sanatındaki yansımalarını incelemektir.

Araștımada, 2000'li yıllarda Türkiye'de fotomontaj tekniğiyle uygulamalar yapan Şahin Kaygun, Ahmet Öner Gezgin, Ali Alişir, Murat Germen ve Orhan Cem Çetin isimli sanatçıların fotomontaj uygulamalarına yer verilmiştir.

Araştırma sırasında, özel sanat galerinin kataloglarından üniversitelerin kütüphanelerinden ve elektronik kaynaklardan elde edilen kuramsal veriler üzerinden taramalar yapılmıştır. Araştırma içinde örnek seçilen sanatçılar ile görüşmeler gerçekleştirilmiştir. Elde edilen veriler çalışmanın içinde sunulmuştur.

Araştırmanın sonucunda, Fotografik görüntüye yapılan müdahalenin günümüzde dijital ortamın olanaklarıla gerçekleştirildiği saptanmıştır ve Türkiye'de 2000'l yıllarda fotomantaj çalışmaları yapan sanatçıların, fotomontajı çeşitli tekniklerle birlikte multidisipliner bir anlayışla kullanıldığı görülmüştür.

Anahtar Kelimeler: Fotomontaj, Kurgusal Fotoğraf, Türk Resmi
Photomontage is an applied technique in many types of Western Art Movements from Dada to Pop Art that constituted from two of different photos' superpose within a new order connection. Photomontage took place in 1980s in which experimental approaches gained importance in Turkish art and continued with the opportunities providing from the area.

Aim of the study is to analyze the artists producing their works with photomontage technique in 2000s in Turkey based upon photomontage technique's place and manner of application in its historical process, and the reflections of photomontage technique in Turkish painting art.

In the research, photomontage applications of Sahin Kaygun, Ahmet Oner Gezgin, Ali Alissir, Murat Germen, Orhan Cem Çetin who use applications in photomontage technique were examined closely.

In the research, the academic data providing from personal art gallery catalogues, university libraries and electronic resources was scanned. We had interview with the artist mentioning in the research. Gained data was presented in the research.

At the end of the research it has been determined that the intervention applied to photographic image was verified with the resource of digital media. It has been seen that the artists applying photomontage in 2000s in Turkey use multidiscipline approach with various techniques.

Keywords: Photomontage, Fictional Photography, Turkish Painting

\section{Giriş}

19. yüzyıl, sanatçıların sanatsal üretimlerinde değişik yöntem, teknik ve malzeme olanaklarından yararlandığı bir dönemdir. Bu dönemde fotoğrafın plastik sanatlarla olan etkileşimi, özgün, dikkat çekici ve aynı zamanda güçlü bir ifade dili olan sanatsal uygulamaları ortaya çıkarmış ve pek çok sanatçı anlatım dili olarak fotoğraf temelli çalışmalar yapmayı tercih etmiştir. Dijital ortamının sağladığı yeniliklerle birlikte günümüz sanatının vazgeçilmez tekniklerinden biri olan fotoğrafik imajlardan farklı görüntüler yaratma anlamına gelen fotomontaj tekniği, gerek karanlık oda yöntemleriyle gerek kes-yapıştır (kolaj) uygulamalarla sanatta deneysel yaklaşımlara olanak tanımıştır.

Tanım olarak "fotoğrafik imajların kullanıldığı kurgu" (URL-9) anlamına gelen fotomontajda,

fotoğrafik öge ile birlikte kullanılan resim ve çizginin sıra dışı etkileri, kontrast nesneler, 
lekelerin dağılımı, siyah beyaz karşıtlığı, uzak yakın ilişkisi, yazı gibi öğeler kompozisyonun sanatsal bir biçim oluşturulmasındaki temel unsurlardır. (Sözen ve Tanyeli, 1994:86). Penguin İngilizce sözcüğü konu ile ilgili olarak; "Birkaç fotoğraftan oluşmuş bileşik resim, bu tür resmi yapma sanatı" ifadelerine yer verir. (URL-2)

Bu çalışmada, Fotomontaj tekniğinin batı sanatı tarihindeki ilk uygulama biçimlerinin incelenmesi, uygulamalardan yola çıkarak dünya sanatına nasıl yön verdiğinin araştırılması ve 2000 'li yıllarda Türk resim sanatındaki yansımalarının incelenmesi hedeflenmiştir. Türkiye'deki sanat ortamında fotomontaj yöntemini kullanarak eser üreten sanatçıların fotomontaja yaklaşım biçimleri çalışmanın konusunu oluşturmaktadır.

19. ve 20. yüzyılın sanatsal ifade yöntemlerinden biri olan fotomontajın kullanımı; ana malzemesi olan fotoğrafın tarihi kadar eskidir. Fotomontaj tekniğinin başlangıcı sayılan ilk örnekler; 1830'lu yıllarda William Henry Talbot'un yaprak ve çiçeklerin ışığa duyarlı fotoğraf malzemesi üzerinde gerçekleştirdiği birbirleriyle ilişkisiz görüntülerdir. Tarihsel süreç içinde Talbot'un koyu bir zemin içinde açık gri tonlu biçimlediği bu ilk deneysel fotoğrafi örnekleri, fotoğrafçılığın temel tanımlarını değiştirecek kadar önemli bir adım olmuştur. (URL-2)

Suprematist Malevich ve Futurist ressam Cara daha önce ilk fotomontaj örneklerini vermiş olmalarına rağmen fotomontaj sözcüğünü ilk defa I. Dünya Savaşı sonrası Berlin Dada grubu tarafından yeni yöntemlerle yapmış olan çalışmaları tanımlamak için kullanılmıştır. Fotomekanik olayın süreklilik kazandığı teknolojik bir dünyanın ürünü olan bu teknik, Dada akımında seçkin kabul edilen yağlıboya resme bir tepki olmuştur. Fotomontaj tanımının aksine Dadaistler fotomontajlarını karanlık oda yöntemleriyle elde etmedikleri için William Rubin bu çalışmaları fotokolaj olarak adlandırır. Sergei Tretyakov ise 1936 'da yazdığı bir yazıda fotomontajı salt fotoğrafların montajı olmadığını, fotoğrafın anlatım, renk ve desen gibi ögelerle zengileştirilerek kurgulanmış bir sanat yapıtı olduğunu savunur. (URL-2)

Konstruktivistler de fotomontajı Dada Akımı sanatçıları gibi görsel bir propaganda aracı olarak kullanmışlardır. Bu yeni ifade yöntemi geniş kültürel bir iletişimin doğmasında etkili olmuş, devrimci politika ve endüstri ürünü teknolojiyi de aynı noktada buluşturmuştur. Sürrealist sanatçılar Fotoğrafların biraraya getirilerek değişik görüntüler oluşturulmasına ek olarak kurşun kalem ve guaj boya gibi sanatsal müdahalelerle fotomontajlarına görsel zenginlik katmış aynı zamanda isimler vermiş ve pasajlar eklemişlerdir.

Geniş bir kullanım alanına sahip olan, değişen, gelişen toplumsal düzen ve ihtiyaçlarla beraber günümüzde sınırsız uygulama örneklerini gördüğümüz fotomontaj tekniğinin sanatsal bir form düzeyinde kullanımı, Batı Sanatındaki uygulama örneklerinden daha eski tarihlere dayanmaktadır.

\section{Materyal ve Yöntem}

Araştırma makalesinde, fotomontajın ilk örnekleri ve batı sanatındaki kuramsal alt yapısı hakkında bilgi verilmiştir. Araştırmanın ana konusunu oluşturan, 2000'li yıllarda Türkiye'de fotomontaj tekniğiyle uygulamalar yapan sanatçılardan Şahin Kaygun, Ahmet Öner Gezgin, Ali Alışır, Murat Germen, Orhan Cem Çetin isimli sanatçıların fotomontaj uygulamaları örnekler ile sunulmuştur.

Araştırma makalesi 2000 'li yıllardan itibaren eserlerinde fotomontaj tekniğini kullanan Türk sanatçılar ile sınırlandııımıştır.

Bu araştırmayı oluşturan veriler farklı disiplinlere ait görsel ve yazılı kaynakların taranmasıyla elde edilmiştir. Literatür taramanın yanı sıra konuya ilişkin görsel örnekler araştırılmış, araştırmada yer alan sanatçılar ile iletişime geçilmiş, sanatçıların çalışmalarıyla görsel bir belgeleme yapılmıştır. 


\section{Bulgular}

\subsection{Fotomontajın İlk Örnekleri}

Işığa duyarlı cam, kağıt ve baskı yapılan zeminlerin elle hazırlandığı 1850'li yıllarda fotoğrafı manipüle ederek gerçek tanımı dışına çıkaran ve gerçekte birebir karşılığı olmayan ilk kurgu fotoğraf sanatçıları; Oscar Gustave Rejlander, Gustav le Gray, Henry Peach Robinson ve Andre Adolphe Eugene'dir (Topçuoğlu, 2000:117). Kariyerine ressam ve portre çizimcisi olarak başlayan İsveçli Rejlander, sembolik, alegorik, resimsel yönü ağır basan ve Rönesans etkisi barındıran fotoğraflar üretmiştir. Sanatçının Raphael'in Atina Okulu çalışmasıyla benzerlik gösteren 1857 tarihli "Two Ways of Life (Hayatın İki Yolu") adlı çalışması bilinen ilk sanatsal fotomontajlardan biridir. Kötülük, merhamet, pişmanlık gibi kavramlara vurgu yapan, dönemin teknolojik şartları düşünüldüğünde teknik ustalığın öne çıktığı bu çalışma, 31x16 inch boyutunda iki kâğıdın birleştirilmesi ve 30 farklı negatif filmin montajlanmasıyla oluşturulmuştur (Şekil 1). Rejlander bu çalışmasıyla fotoğrafı sadece gerçeği betimleyen teknik özelliğinin dışına çıkarmış ve aynı zamanda günlük hayattan kesitler sunan fakat kullandığı semboller ve yarattığı kurguyla kendi gerçekliğini ortaya çıkaran bir eser üretmiştir. (URL-12)

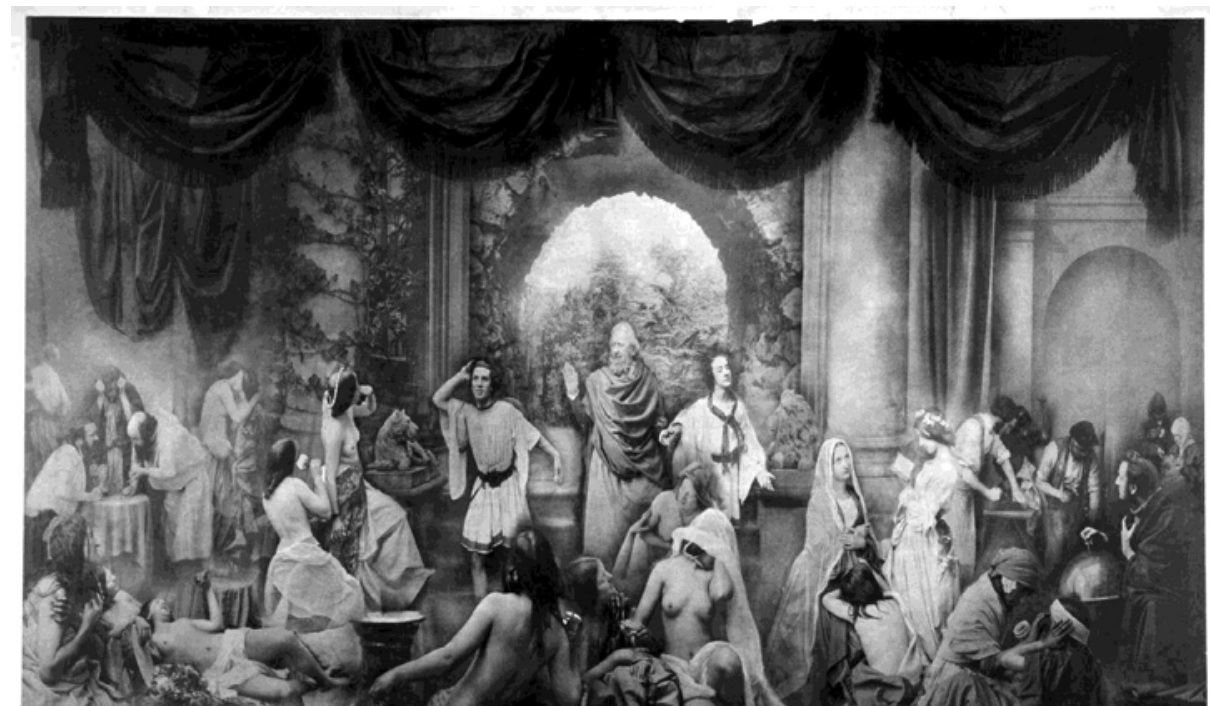

Şekil 1. Gustave Rejlander, "Hayatın İki Yolu" (The Two Ways of Life), 1857

19. yüzyıl sanatçısı Eugene Disderi çalışmalarında "Dizme", "Çoğaltma", "Aynı Anda Sunma" ve "Parçaları Birleştirme" kavramlarını kullanarak fotografik görüntüye müdahalede bulundu. Özellikle "Balerin Bacakları" isimli fotomontajında "kesme", "çoğaltma" yöntemleriyle birçok balerin bacağını aynı fotoğrafta toplamıştır (Şekil 2). (URL-1) 


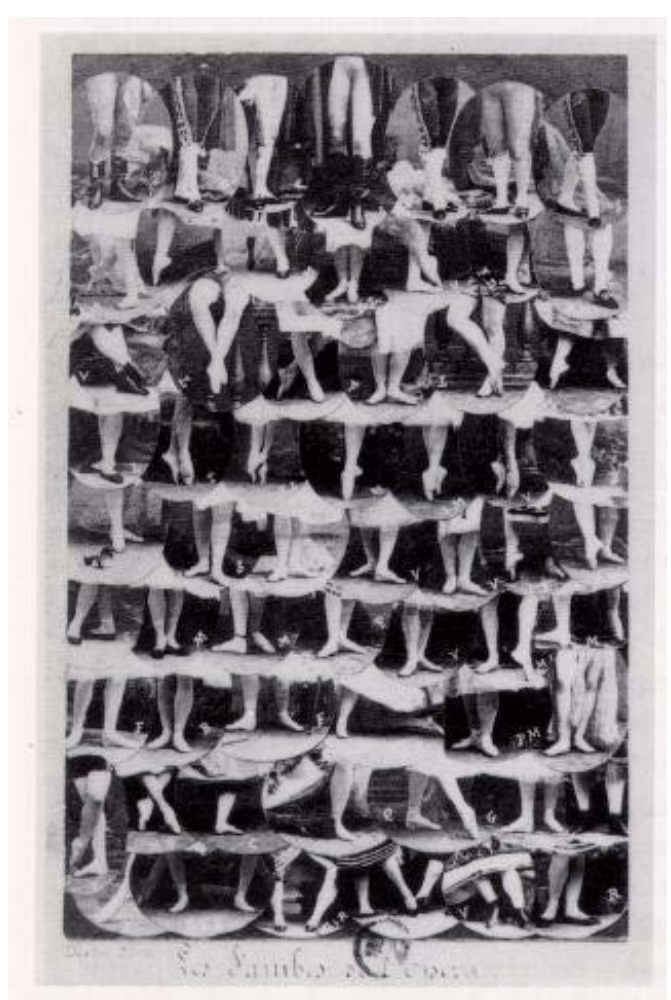

Şekil 2. Eugene Disderi, Balerin Bacakları, 1858

Yine aynı yılda yapılmış olan Prens Lobkowitz adlı çalışma Disderi'nin kesme ve ekleme işlemleri kullanarak prensin çeşitli görüntülerinin aynı kare içinde kurgulandığı bir çalışmasıdır. Potre fotoğrafçılığındaki ustalığıyla bilinen sanatçı, aynı zamanda bir filmden birkaç baskı yapma tekniğini ustaca kullanmıştır.

Fransız asıllı sanatçı Gustave Le Gray tek bir yüzeyde birden çok fotoğraf kullanarak fotomontajın ilk örneklerinden biri olarak kabul edilen Büyük Dalga (1850) isimli çalışmasını yapmıştır. Ayrı ayrı pozlandırdığı gök ve deniz negatifitini aynı düzlem üzerinde bir araya getirmiş ve birçok kompozit (Değişik tarzları bir arada taşıyan) baskı denemiştir (Şekil 3).

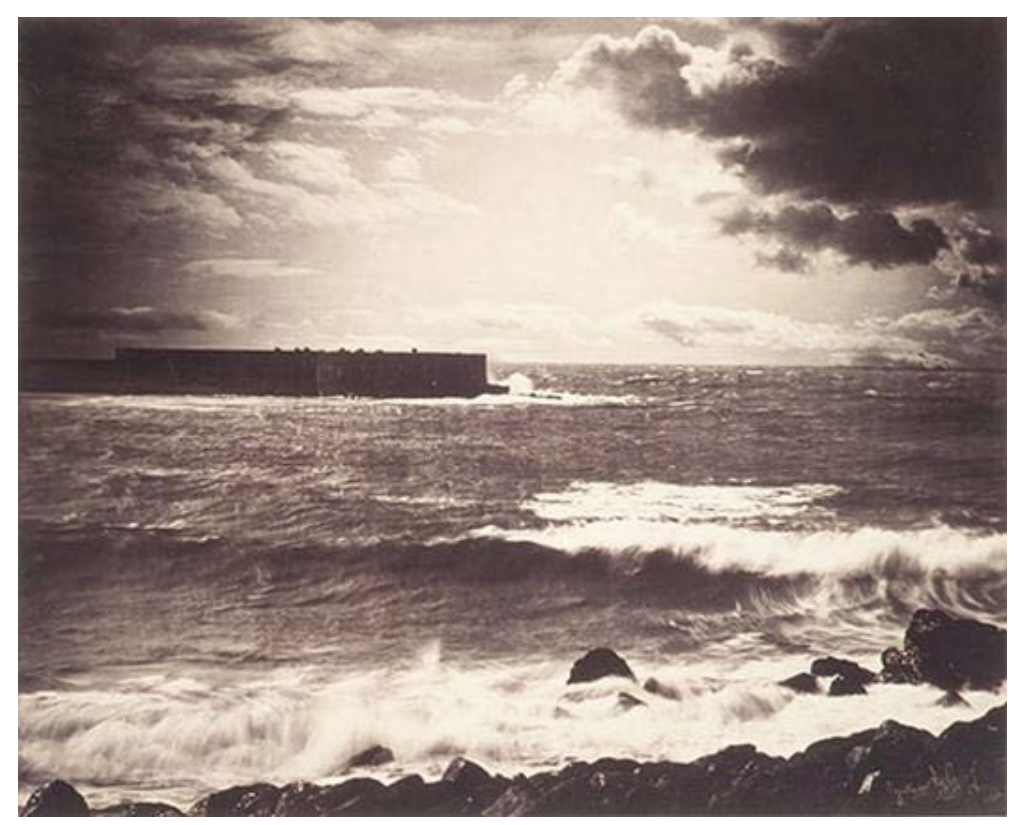

Şekil 3. Gustave Le Gray, (The Great Wave) Büyük Dalga, 1850 
19. yüzyılda fotoğrafı kurgu (montaj) olarak ele alan sanatçılardan biri de İngiliz Henry Peach Robinson'dur. Robinson'un "Fading Away" (Solup Gidiş) isimli çalışması Victoria döneminde yapılan romantik etkileri olan ilk fotomontaj çalışmalardan biri olarak bilinmektedir. Beş ayrı negatiften üretilmiş bir fotoğraf baskısı olan bu çalışma, hasta yatağında ölmek üzere olan hasta bir kızı ve çevresinde toplanmış olan aile bireylerini gösterir. Kuvvetli gerçeklik etkisi ve güçlü kurgusu, bu kadar acıklı ve üzücü sahnenin fotoğraflanmasına alışkın olmayan Kraliçe Victoria dönemini halkının tepkisine neden olmuştur (Topçuoğlu, 2000:127) (Şekil 4).

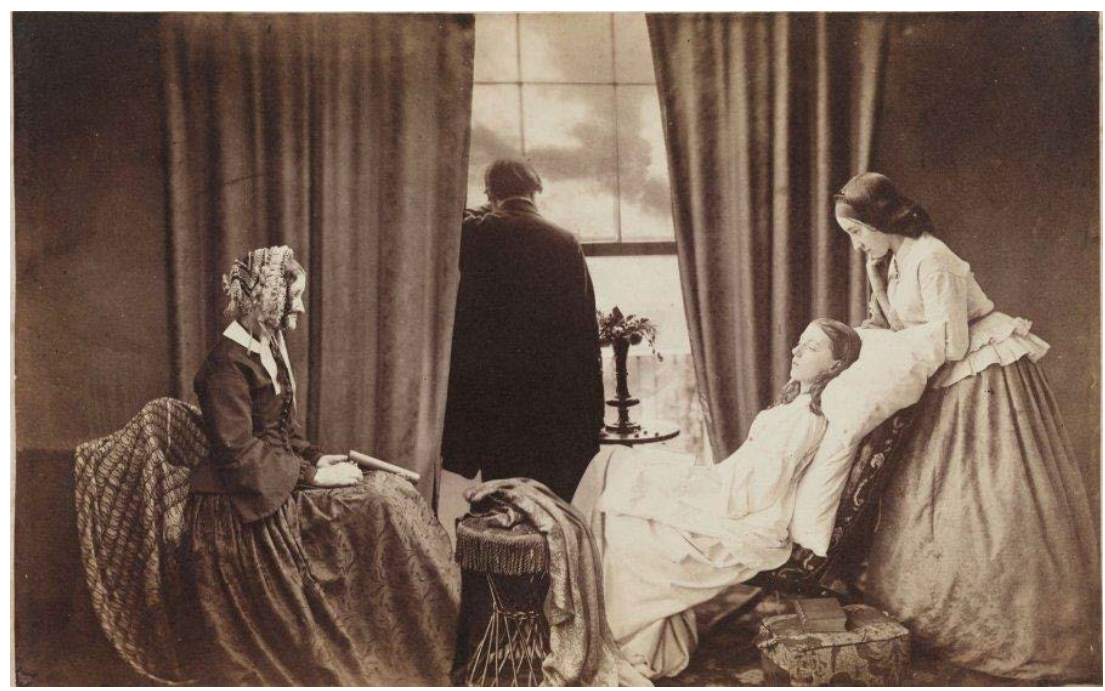

Şekil 4. Henry Peach Robinson Sönüş (Fading Away), 1858

\subsection{Fotomontaj ve 20. Yüzyıl Batı Sanat Akımları}

Tarihsel süreç içinde fotoğrafik imgelerin sanat akımlarında farklı kurgular içinde kullanılması söz konusu olmuştur. Fotomontaj tekniği, Batı sanat akımlarında gerçekliği farklı bir bakış açısıyla sunan en çarpıcı yöntem ve fotoğrafı da bu tekniklere uyarlanabilecek en uygun materyal olarak kullanılmıştır.

Penguin İngilizce Sözlüğünün "Birkaç fotoğraftan oluşmuş bileşik resim, bu tür resmi yapma sanatı." olarak adlandırmış olduğu fotomontaj; teknik olarak; seçme yapıştırma şeklinde, farklı tekniklerin bir arada kullanılması veya karanlık oda deneylerini içermekteydi. Ancak Fotomontaj tekniği Dadaistlerle birlikte farklı bir anlam kazanmış, sanatçılar gün geçtikçe zenginleşen ve toplumsal bellek yaratan fotoğrafik imgeleri, kurgularında kışkırtıcı ve propogandist etkiler yaratacak şekilde kullanarak foto-kurgular (fotomontajlar) yapmışlardır.

Dadaistler kes-yap yöntemiyle bir araya getirdikleri fotomontaj uygulamalarında;

"Fotoğrafik kurgunun yaratacağı anlatımdan çok patlama ve kargaşa etkisi amaçladı. Bu nedenle imgeler arasındaki ilişkiler pek irdelenmiyor, bunun yarattığı karışıklık, sıradanlık ve çirkinlik hem estetik dışı, hem kışkırtıcı tavırlarına en uygun yol olarak görülüyordu. Bildiri, yapının bütünlüğünün taşıdığı görsel etkide gizliydi. Düzenlemeler, fotoğrafik imgelerin yanında, çeşitli boy ve renklerdeki sözcükler ya da harflerle kurgulanmaktaydı..." (İslimyeli, 1978: 38).

William Rubin 1968 yılında New-York Sanat Müzesi'nde açılan sergide bulunan Dada fotomontajlarına, karanlıkoda yöntemleriyle elde edilmedikleri için "foto-kolaj" ifadesini kullanır. Sergie Tretyakov 1936'da William Rubin'in tersi bir anlayışla fotomontajı salt fotoğrafların montajı olarak görmediğini; fotoğrafların anlatım, renk ve desen gibi öğelerle 
zengileştirilmiş bir yöntem olduğunu savunmuştur. Ayrıca Tretyakov Dada fotomontajlarına anlam ve kavram bakımından şu ifadelerle açıklık getirir:

"Eğer fotograf anlamın etkisi altındaysa ve görülen anlamın dışında o anlamın toplumsal bir anlatımını, eğilimini içeriyorsa, o gerçek bir fotomontajdır." (URL-2)

Berlin Dada grubunu sanatçıları John Heartfield, Raoul Hausmann, Hannah Höck, Richard Huelsenbeck ve George Grozs I. Dünya Savaşı'nın, getirdiği kargaşadan sonra daha güçlü bir tavırla iktidarı ele geçiren Hitlerin dikta rejiminin nasyonalist tutumunu fotomontajlarıyla eleştirmişlerdi. Hannah Höck bir çalışmasında;

"Fotomontaj tekniğine ilk kez Alman askerlerinin kendileri, arkadaşlarını ve ailesini eğlendirmek için dergilerden aldıkları resimler ile kendi fotoğraflarını birleştirerek yaptıkları kartpostalları evlerine göndermeleri sayesinde rastladıkları" ifadelerine yer vermiştir (Ergün, 2012: 9).

Aynı zamanda Höck fotomontaj eylemi için sanat dünyası ve makine endüstrisi dünyasının birlikteliğinin amaçlandığı ifadelerini kullanır (Şekil 5).

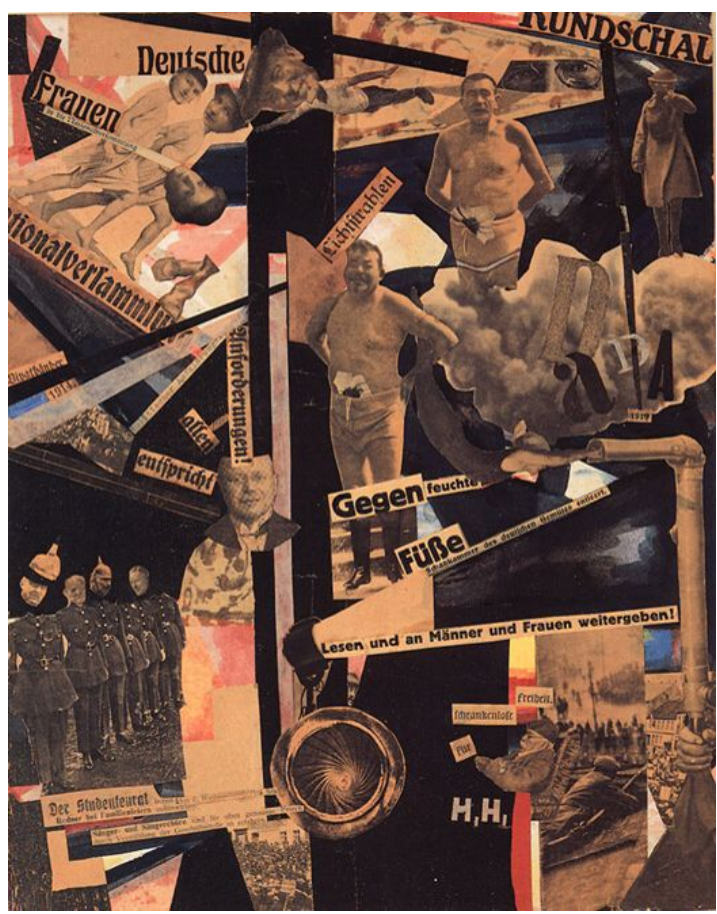

Şekil 5. Hannah Höch, Dada panoroma, fotomontaj, 1919

Fotomontaj tekniğini ustalıkla uygulayan en önemli sanatçılardan biri Berlin doğumlu John Heartfield'dır. Sanatçı tüm Dada akımı sanatçıları gibi I. Dünya savaşını ve Hitlerin yarattığı toplumsal kıyımı protesto etmiş, toplumun içinde bulunduğu bunalımı çeşitli fotoğrafları bir araya getirerek oluşturduğu politik fotomontajlarıyla eleştirmiştir. Dadaistler (Şekil 6) tarafından salt fotomantajlarından dolayı değil, tam tersine var olan sanatsal düzene karşı duruşu ve ortaklaşa paylaştıkları fikirlere sahip çıktığından "montajcı Heartfield" olarak bilinen sanatçının fotomontajları anlatım yönünden dolaysız, fakat bildirişimleri karmaşıktır. (URL-2) 


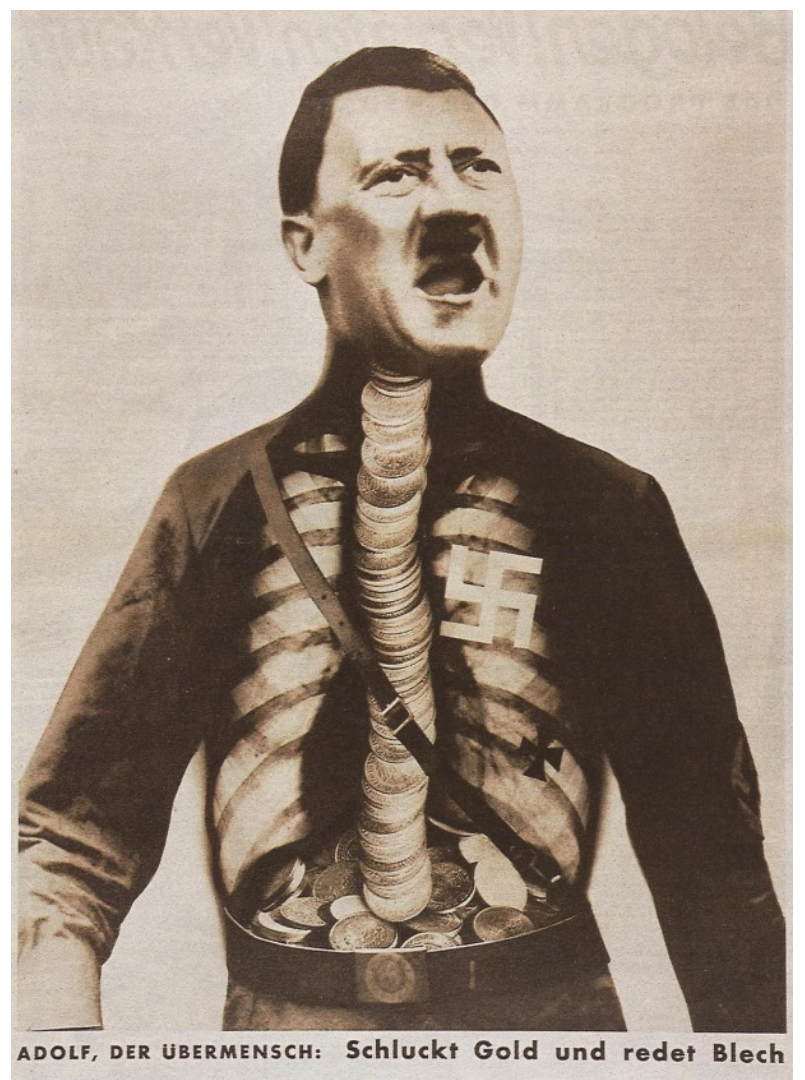

Şekil 6. Hannah Höch, Dada panoroma, fotomontaj, 1919

Rus konstrüktivistler o dönemlerde fotoğrafik materyallerle karşılaştılar ve Dadaistlerle benzer nedenlerle fotomontajı kullanmaya başladılar. Konstrüktivizmin temsilcilerinden olan Rus ressam, tasarımcı ve fotoğrafçı Alexander Mihaylovich Rodchenko(1891-1956) ve onu izleyen öncü sanatçılar Fotomontajı sanat anlayışlarını ifade eden öncü, ideolojik ve çağdaş sanatta yeni bir form olarak sıklıkla kullandı. Rodchenko sanatı, hangi kolu olursa olsun burjuva değerlerini yansıtan bir uğraş olarak düşünmekteydi. Bu sebeple kısa bir zaman sonra resmi bırakmış ve bir üretimci olarak, tasarıma yönelmişti. Alışkanlıklara karşı çıkmak ve gerçeği farklı açılardan göstermek isteyen sanatçı için Yılmaz şunları söylemiştir:

"sanatdışı saydığı afiş, tasarım, film ve fotoğraf alanına üretimler yapmaya başladı. Bunun için balkonları, şehir manzaralarını, merdivenleri, tren istasyonlarını, resmigeçit törenlerini, siyasal liderleri ve değişik mekanlardaki iş̧̧ileri çekmiş; kompozisyonu birbirini kesen çaprazlarla kurguladığı, 'aşağıdan yukarı ve yukarıdan aşağıya olan çekimlerle geleneksel fotoğrafi anlayışııın dışına çıkan eserler üretmiştir" (Yılmaz 2013:385). 


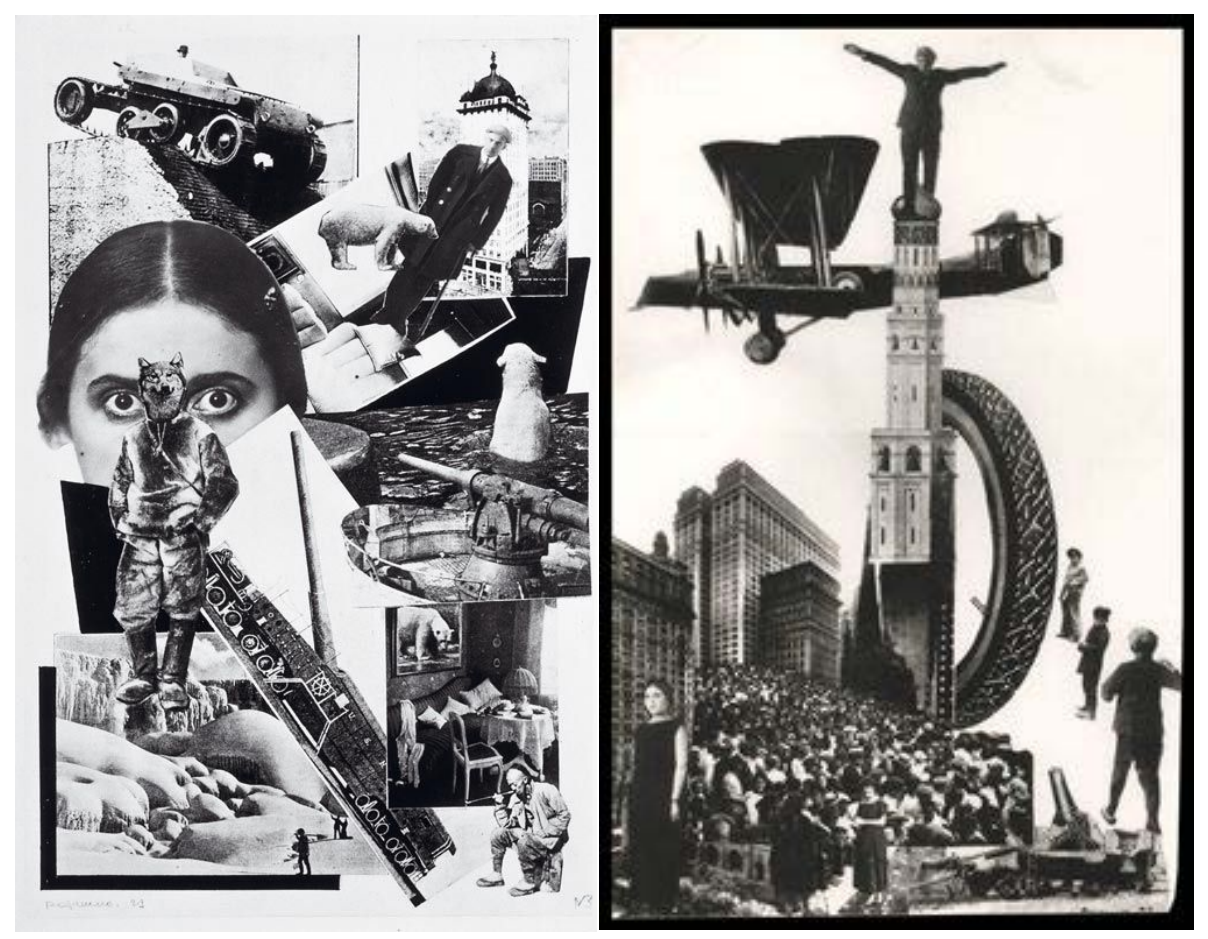

Şekil 7. Alexander Rodchenko, Mayakovsky'nin bir şiiri olan Pro Eto için hazırlanan fotomontajlar, 1923

Rodchenko ve Rus konstrüktivistler teknik anlamda fotomontajda öncü Grosz'la Heartfield'in yapıtlarına hayranlık duyuyorlardı. Rusya'nın o dönemdeki siyasal durumu konstrüktivistlerin fotomontajı Grosz ve Heartfield'in kullandığı gibi polemik amaçlarla kullanmalarına elverişli değildi. Burjuva resim sanatından fazlasıyla uzaklaşan Rohchenko'nun Mayakovsky'nin bir şiiri olan "Pro Eto" için hazırladığı fotomontajlarına bakıldığında Heartfield'in çarpıcı ve özlü anlatımının yanında Pro Eto'nun üslubu bilinçli bir gevezeliği yansıtıyordu. Bu görüntü (Şekil 7) Mayakovsky'nin şiiri gibi sınırsız sayıda çoğaltılabilecek bir nitelikte karşımıza çıkar ve yalnız tek örneği olan bir sanat yapıtı izlenimi vermez. Bu fotomontajda, Rodchenko kullandığı fotoğrafik malzemeyi açıkça öne çıkarmış, basit geometrik biçimlerle elde edilmiş birkaç figüratif çizginin dışında, tümüyle soyut bir eser elde etmiştir. Lynton (1991) Rodchenko'nun bu fotomontajlarda üslup bakımından Kübizm-Fütürizm ve Grosz-Heartfield'in yenilikçiliğinin aynı dönemiyle ilgili 1919 dada-merika kolajlarındaki görüntü dilini aşamadığını ifade etmiştir. Yapıtlarını perspektif etkiden uzak yüzeylerle ve çoğunlukla nokta, çizgi gibi kompozisyon elemanlarının kurgulanmasıyla oluşturan Rodchenko, 1924 yılında çeşitli fotoğrafik imajları kullandığı bir seri fotoğraf çalışması yapmış, baskılarında oklar, bloklar, çizgiler ve kırmızısiyah gibi kontrast renk ögelerini de kullanmıştır. 


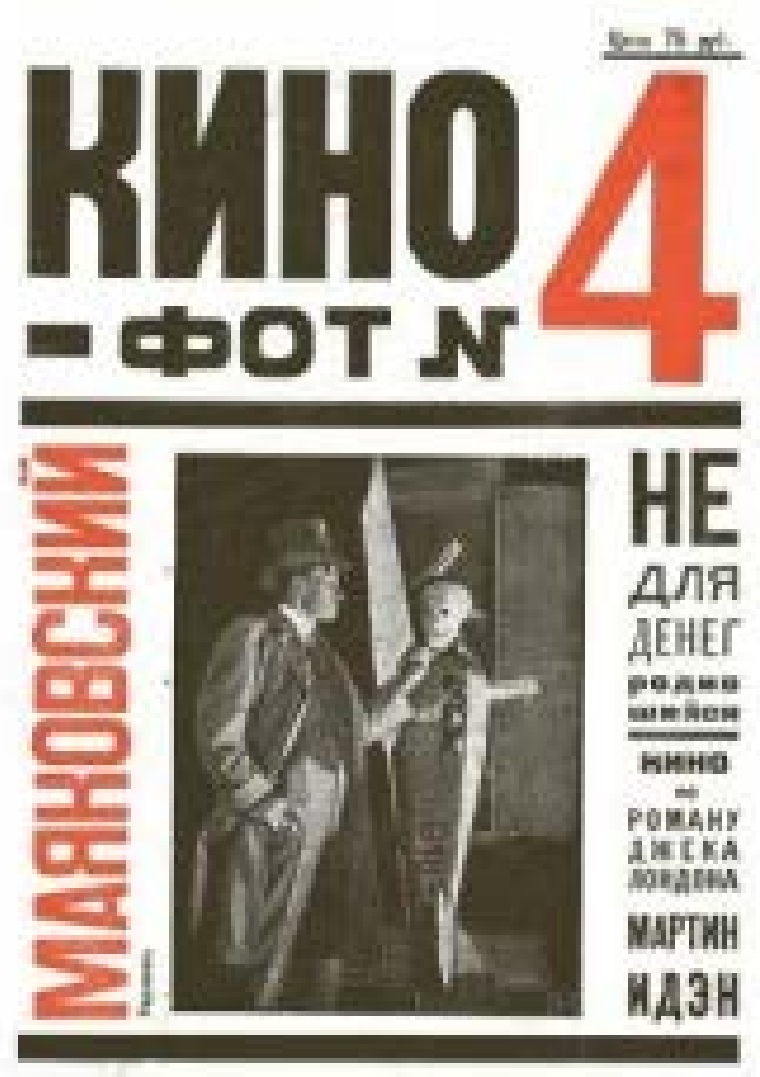

Şekil 8. Kino-fot dergisinin kapakları, fotomontaj,

1920'li yıllarda fotomontaj çalışmalarıyla öne çıkan isimler Man Ray (1890-1976) ve Laszlo Moholy-Nagy (1895-1946) olmuştur. Çok yönlü bir sanatçı olan Man Ray gerek Dada gerekse Sürrealist akım etkileri gösteren resimden heykele ve tasarıma, fotoğraftan sinema ve yazıya kadar birçok alanda eserler üretmiştir (Şekil 9). 1915 yılında açtığı ilk resim sergisinde kesyap ve kurgu konusunda olumlu eleştiriler alan sanatçı, fotoğrafla tanışmasıyla birlikte çalışmalarını fotoğraflayama başlamış ve bir süre sonra fotoğrafla farklı yöntemler denemiştir. Ray karanlık oda deneyleri yaparken kendine ait baskı yöntemi olan 'Rayogram' tekniğini geliştirmiş, bu teknikle;

"fotoğraf kağıdının üzerine bazı nesneler yerleştirip ışıklandırmış, ortaya çıkan görüntüyü daha sonra yeniden başka bir kağıda aktararak ilginç görüntüler yakalamış, buna da rayogram adını vermiştir." (Yılmaz, 2013:386). 


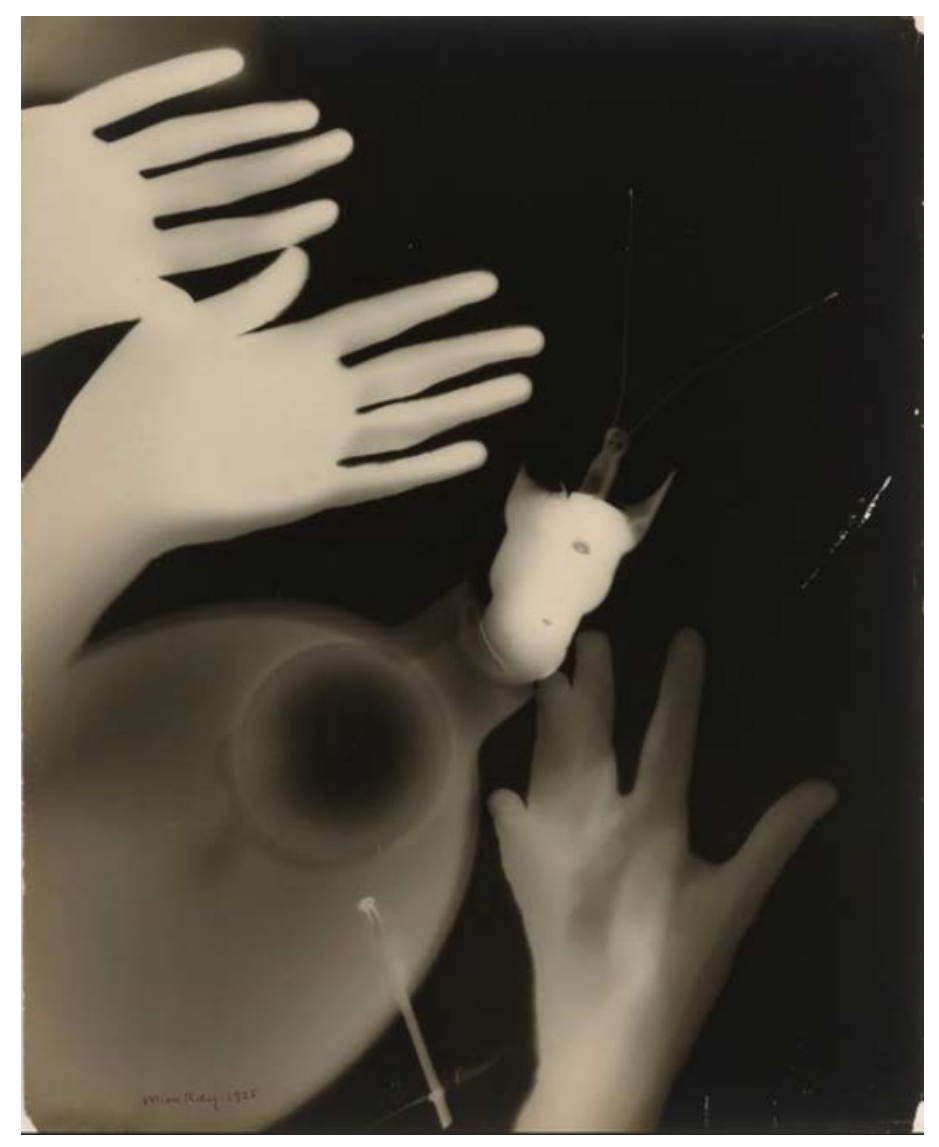

Şekil 9. Man Ray, Rayogram, Rayographie (Rayograph), 50 x 40.5 cm, 1925

Rayogram tekniğiyle yaratmış olduğu görüntülerle gerçeküstü fotoğrafçılığın ilk örneklerini veren Ray çalışmaları için "sadece mümkün olduğu kadar özgür olmaya çalışırım" diyerek üretim sürecindeki bağımsızlığını ifade eder. Rayogram her ne kadar bir fotoğraf tekniği olsa da fotoğrafla soyut görüntüler yaratması bakımından öncü ve yaratıcı bir teknik olarak sanat dünyasında alternatif yöntemler arayışında olan pek çok sanatçı tarafından da ilgi çekici olmuştur (Sucuoğlu, 2016:201). Sanatçı rayogramla yarattığı görüntülerde nesnelerin görünüşünden ziyade nasıl algılandığına önem vermiş, Ingres Kemanı isimli çalışmasında sevgilisi Kiki'yi model olarak kullanmış ve f deliklerini rayogram tekniğiyle yapmıştır (Şekil 10). 


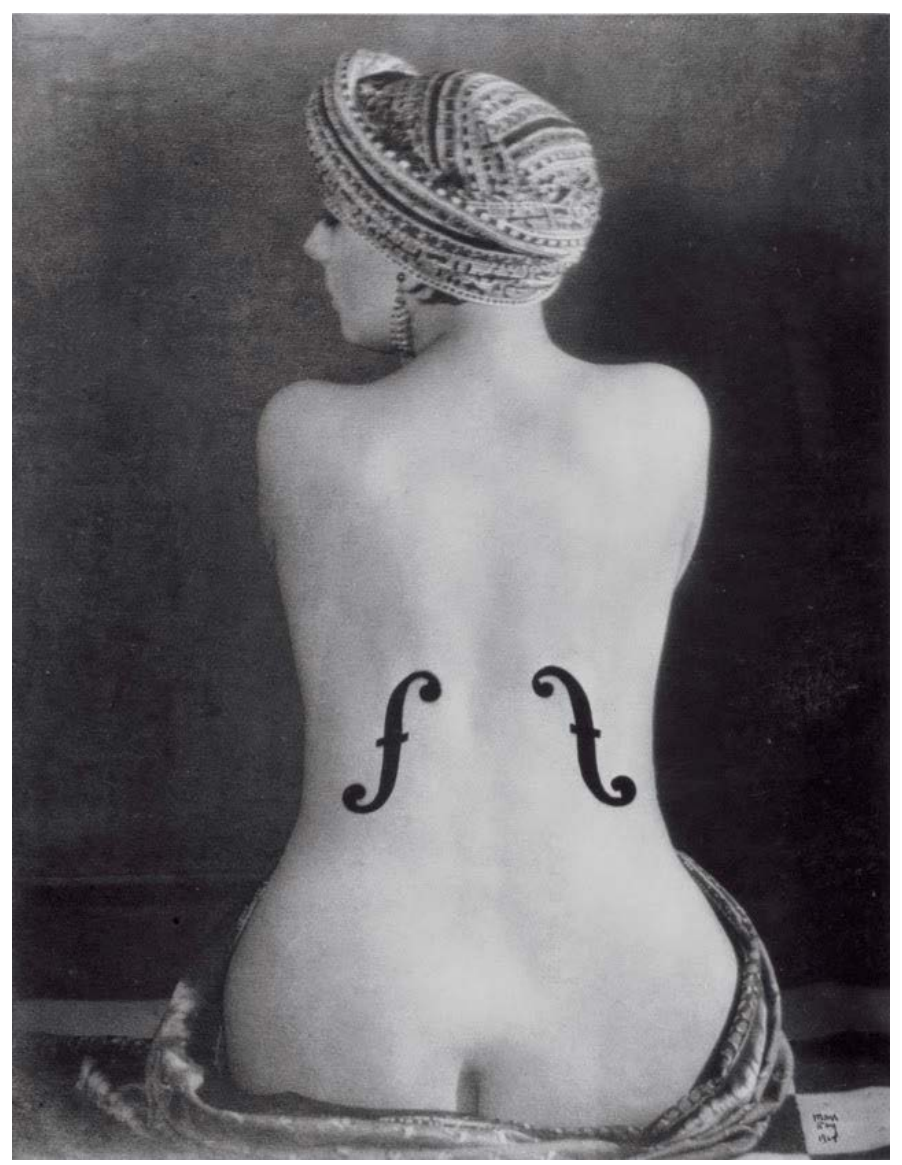

Şekil 10. Man Ray,Ingres kemanı (Kiki), Fotoğraf (rayogram) 38,6×30 cm, 1928

Macar sanatçı Moholy Nagy de Man Ray gibi çalışmalarında çift baskı yöntemlerini geliştirerek "fotogram" olarak adlandırılan teknik yoluyla yeni karanlık oda deneyleri yapmıştır. Nagy'in fotoğrafçılığa sağladığı en önemli tekniklerden biri olarak kabul edilen fotogramda, negatif kullanmak yerine fotoğraf kağıdının üzerine koyduğu nesnelerin ışık yardımıyla oluşan görüntüleri elde edilmektedir. Sanatçı, Ray'le aynı yıllarda Almanya'daki Bauhaus tasarım okulunda bu tekniği kullanarak çeşitli eserler üretmiştir. 


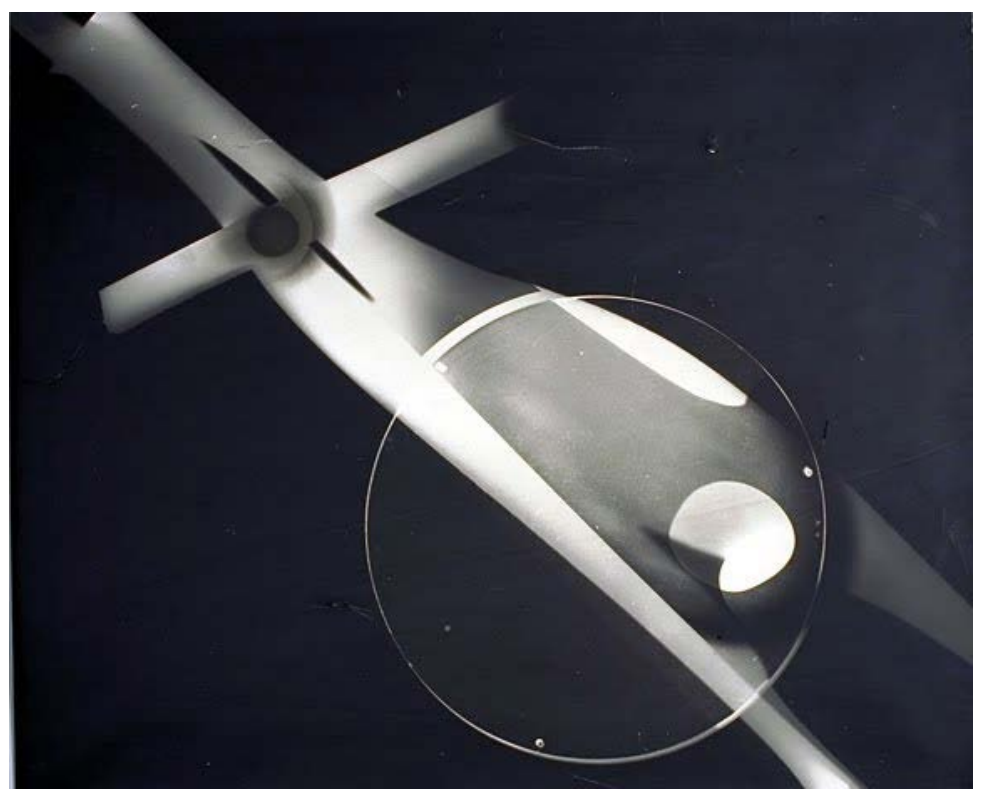

Şekil 11. Laszlo Moholy-Nagy, fotogram, fotoğraf, 30x40cm, 1928

Nagy'in bu eserinde (Şekil 11) görüldüğü gibi fotogramdaki şekiller, kullanılan nesnelerle aynı boyutta ve şekilleri bozulmamıştır. Ancak bu nesneler tanımlanabilir netlikte olmayan geometrik soyutlamalardır.

Mehmet Yımaz, Moholy-Nagy'in fotoğraf sanatındaki deneysel tavrını şu ifadelerle açıklar:

"Meraklı bir sanatçı ve hoca olarak eski ve yeni tekniklerin doğasını inceleyen MoholyNagy, 1925'te Resim, Fotoğraf ve Film adında kitap yazmıstır. Ona göre fotogram, fotoğrafın gerçek anahtarıydı. Herhangi bir kamera kullanmaksızın, ışığa duyarı malzeme yüzeyinde ışığın yakalanmasını sağlayan, fotoğrafik sürecin özünü somutlaştıran yepyeni bir yöntemdi. Özetle, yeni bir görüş̧ peşinde koşanların elinde, optik görüntüleme daha önceden bilinmeyeni açığa çıkaran çok güçlü bir silahtı" (Yılmaz, 2013:38).

\subsection{0 'li Yıllarda Türkiye'de Fotomontaj Tekniğini Uygulayan Sanatçılar}

Osmanlı'nın yenilenme hareketi olarak adlandırılan Tanzimat (1839-1876) (I.Abdülmecid/ Abdülaziz) ve II. Abdülhamit (1876-1909) döneminde ilk fotoğrafi çalışmalar yapılmıştır. Ancak Osmanlı'ın Batı tarzı yenilenme hareketinin yüzeysel olması, İslam dininde insan tasvirinin yapılamıyor olması, batı kaynaklı ıslahatların toplum tarafından destek görmemesi, ekonomik güçlükler ve teknolojik ilerlemenin gerisinde kalınmış olması, fotoğrafın Osmanlı sınırları içinde yeterli ilgiyi görmemesine sebep olmuştur. Bu dönemde fotoğrafi yalnızca Osmanlı sınırları içindeki gayrimüslimlerin ve Şark'ın yaşantısını egzotik ve hayali bir bakış açısıyla ele alan Batı dünyasının tekelinde kalmıştır. Abdullah Biraderler ile önem kazanmaya başlayan Türk fotoğraf sanatı, geçmişten günümüze kadar pek çok tekniğin uygulandığı bir alan olmuştur. Bu dönemde Abdullah Biraderler'in, Batılı toplumların zihnindeki Doğu ve Osmanlı algısının 19. yüzyıldaki yansımaları olan fotoğraflarına, kurgusal fotoğrafın ilk örnekleri diyebiliriz (Gülaçtı, 2018). 


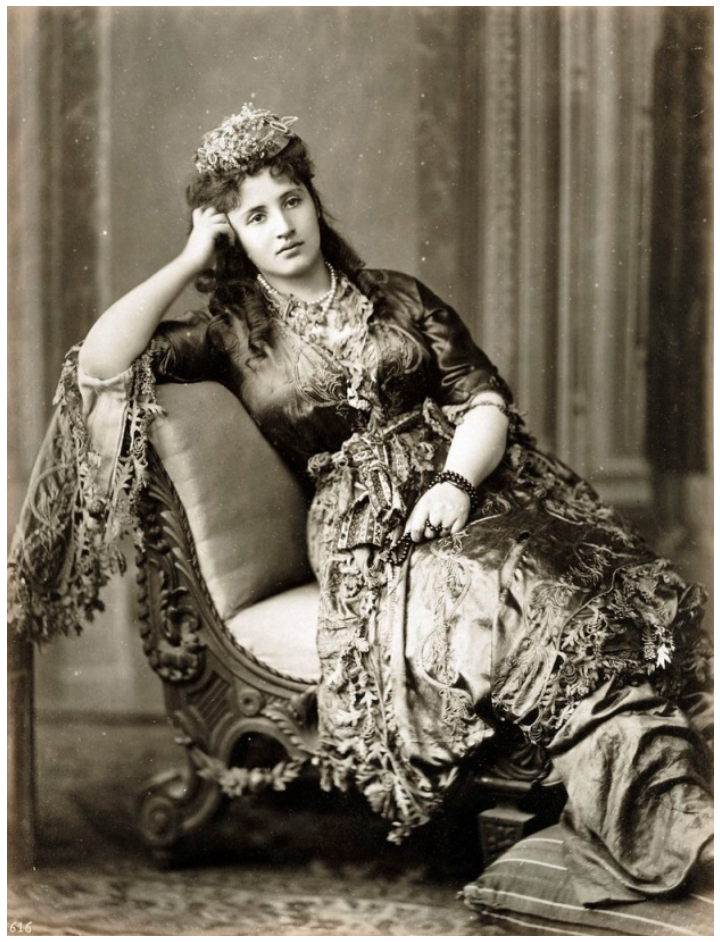

Şekil 12. Abdullah Biraderler'in Türk Kadını Fotoğrafı, The History of Photography Archive,

Fotoğrafinin ülkemizde görsel iletişim sistemi içinde uygulama alanı bulması, çağdaş toplumun ihtiyaçlarına cevap verebilecek bir iletişim aracı haline gelmesi Cumhuriyet dönemiyle başlayan bir süreç olmuştur. Cumhuriyet sonrası canlanan kültür sanat ortamında resim ve heykel gibi fotoğraf da batıdaki oluşumlara kapalı kalmamış; toplumu "muasır medeniyet seviyesine" çıkarma amacında olan yeni yönetim biçimi, propagandasını geniş kitlelere ulaştırabilmek için fotoğrafinin çoğaltma ve yaygınlaştırma özelliklerinden yararlanmıştır. (Gezgin, 1995).

Türk fotoğraf sanatçıları Cumhuriyet dönemiyle birlikte 1980'li yıllar arasındaki dönemde politik olayların etkisiyle değişen toplumsal olaylara objektifleriyle ışık tutmuşlardır. Belge fotoğrafçılı̆̆ının önem kazandığı bu dönemde Anadolu'yu gezerek köyleri, beldeleri ve Anadolu insanının yaşamını geleneksel yöntemlerle belgeleyen Ara Güler, Ozan Sağdıç, Hüsnü Gürsel, İbrahim Zaman, Sabit Kalfagil, İsa Çelik, Mustafa Kapkın gibi sanatçılar Türkiye'de belgesel fotoğrafın öncü isimleri olmuşlardır (Gezgin, 1995).

1980’li yıllara gelindiğinde belgesel niteliğindeki fotoğrafçılık yerini deneysel yaklaşımların ağırlık kazandığı uygulamalara bırakmış; sanatçılar fotoğraf makinesinin tanımış olduğu düz anlatım olanaklarının dışına çıkan yeni arayışlar içine girmişlerdir. Betimlemeye dayalı ve sosyal gerçekliği gözler önüne seren klişe yaklaşımların ötesine geçen avangard veya deneysel fotoğrafinin önem kazandığı bu dönemde fotomontaj tekniğinin ilk örnekleri görülmektedir.

Türkiye'de deneysel fotoğraf anlayışına salt karlık oda yöntemlerinin dışında; teori, estetik ve teknik birikimlerini dışavurumcu ve özgün bir ifade tarzıyla ortaya koyan Şahin Kaygun ve Ahmet Öner Gezgin, öncülük eden isimlerdir. 80'li yıllarda fotoğrafta klasik anlatımın ötesine geçen ve fotomontaj uygulamaların da dahil olduğu deneysel fotoğrafi kavramının felsefesini savunan Ahmet Öner Gezgin ve fotoğrafı pentürel düzlemde biraraya getiren Şahin Kaygun, fotoğrafı yaratma eylemi içinde nesnel gerçekliğin ötesini bir araç olarak kullanmışlardır(Gezgin, 1995). 
80’li yıllarda başlayan sanatçının yaratıcı gücünün ve estetiğin önem kazandığı bu anlatım dili, 2000'li yıllara kadar devam etmiştir. Dijital fotoğraf dönemi olarak adlandırılan 2000'li yıllar, teknolojinin sağlamış olduğu olanaklarla sanatçıların fotoğrafların manipülasyonunu kolaylıkla yapabildiği bir dönemdir.

\subsection{1 Şahin Kaygun (1951-1992)}

1972 yılında Devlet Tatbiki Güzel Sanatlar Yüksekokulu, Grafik bölümünde eğitim gören Şahin Kaygun fotoğraf ve resim sanatını biraraya getirdiği foto-pentür eserler üretmiştir. Çalışmalarında karanlık oda müdahalelerinin yanı sıra boyama ve kazıma gibi alışılagelmişin dışında uygulamalar yapan sanatçı, Türk sanatında deneysel fotoğrafın ilk örneklerini vermiştir (Sezer, I. ve Demircan, 2016:45).

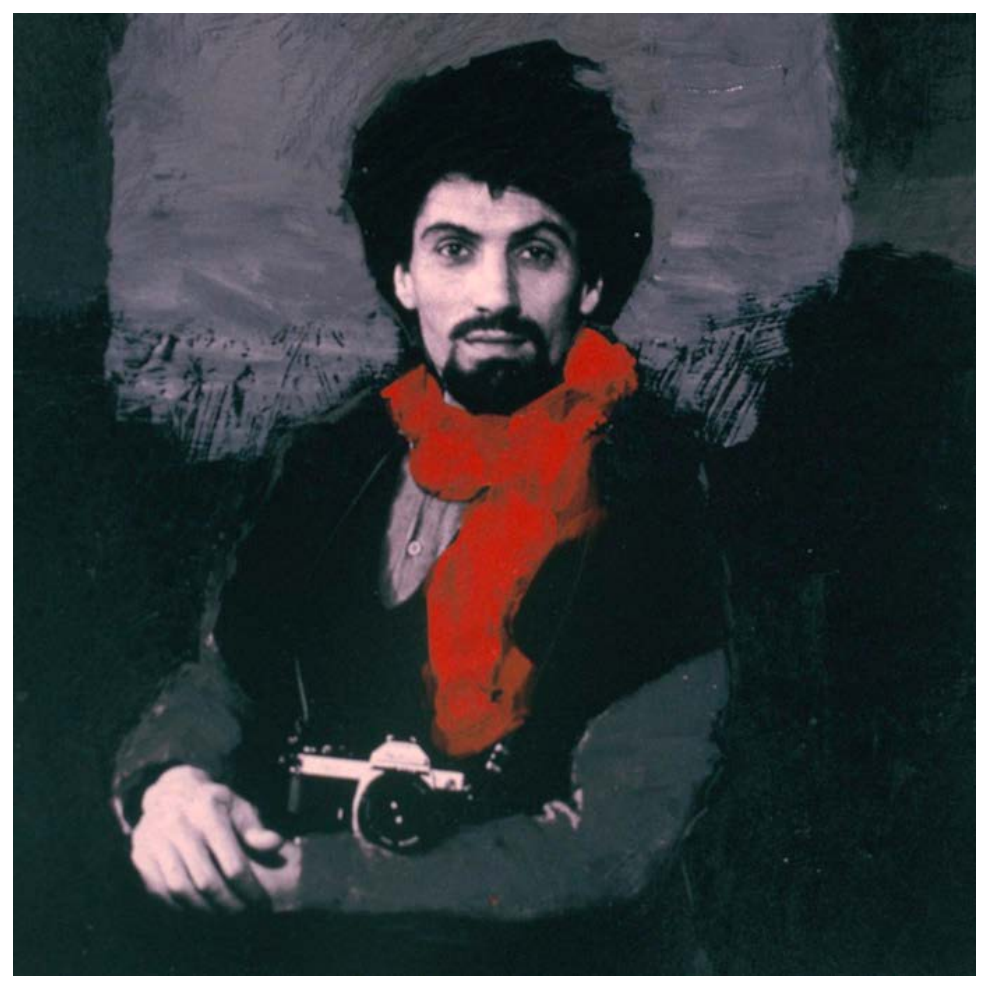

Şekil 13. Şahin Kaygun, Öz Portre, 1991

İstanbul Devlet Tatbiki Güzel Sanatlar Yüksek Okulunda Grafik ve fotoğrafçılık eğitimi alan sanatçı, profesyonel eğitiminden önce sanat yaşantısına desen çizerek başlamıştır. Kaygun'un, resimdeki bu kabiliyeti zaman içinde resim ve fotoğrafı biraraya getirdiği eserlerinde görülmektedir. Fotoğrafın sınırlarını zorladığı polaroid fotoğraflarında fotomontaj, boyama, kolaj, kazıma ve yakmalar yaptığı; fotoğraf üzerine resim veya resim üzerine fotoğraf yapma gibi farklı teknikler kullandığı eserleri Türk fotoğrafına yeni yaklaşımlar kazandırmıştır (Doğan, 1984:47). 
Polaroid fotoğraflar üzerinde farklı malzeme ve teknikleri deneyerek değişik etkiler yaratmaya çalışan Şahin Kaygun, eserlerinde görsel olarak heykeller, deniz kabukları ve oyuncak bebekler ve çeşitli simgesel öğelerden yararlanarak kendine ait yeni dışavurumsal bir dil geliştirmiştir. Resmi ve fotoğrafı ustalıkla harmanlayan sanatçı, yaratıcı gücünün vermiş olduğu tutkuyla "fotoğraf çekmek ile fotoğraf yapmak" arasındaki farkı kısa süren hayatında eserleriyle izleyiciye ulaştırmıştır. Şahin Kaygun o güne değin üretilen eserlerde izlenilen folklorik ve egzotik unsurlar yerine varolma sorunu ve evrensel değerleri, özgün ve güçlü üslubuyla izleyiciye aktarmıştır (Soylu ve Yıldırım, 2008:340).
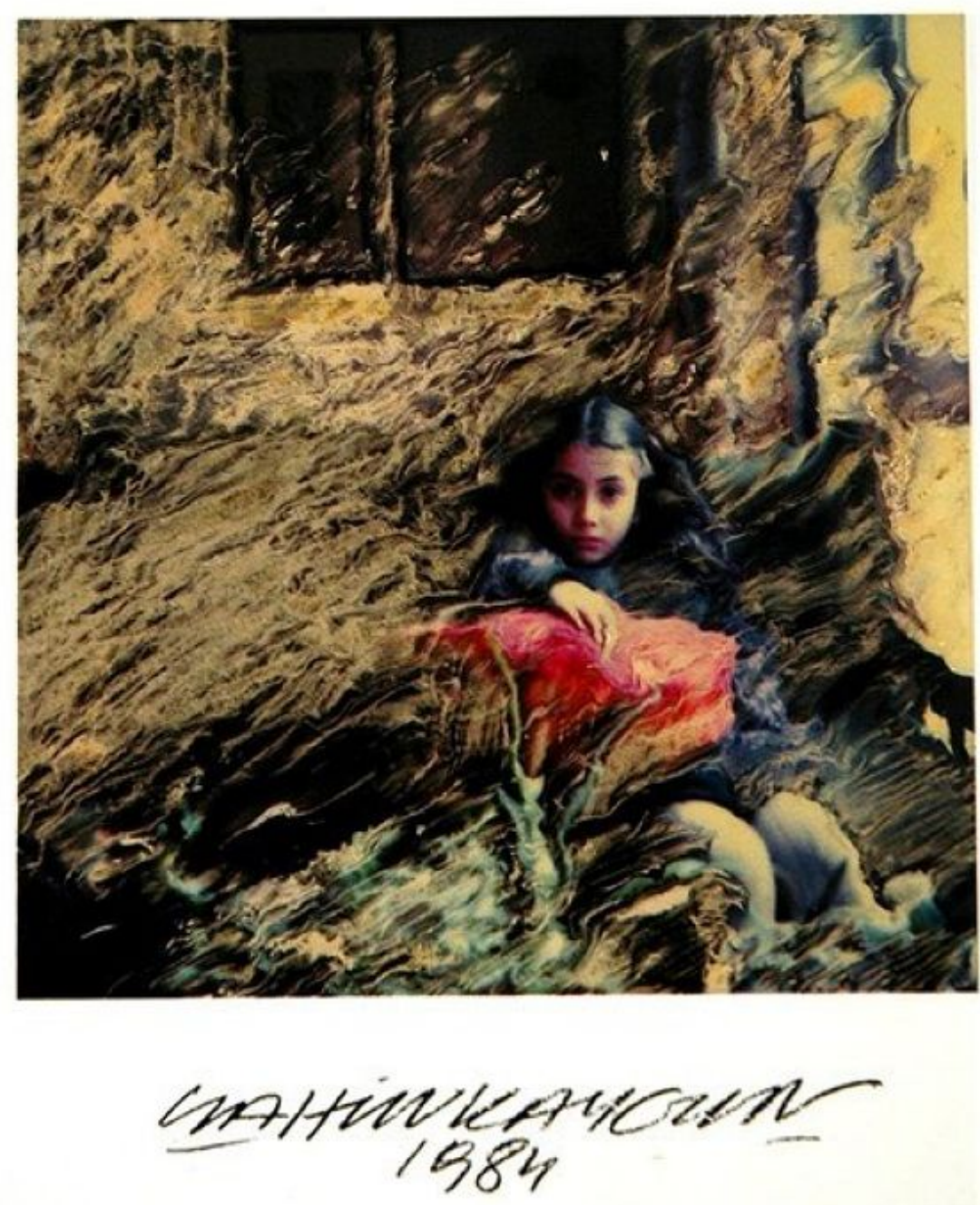

Şekil 14. Şahin Kaygun, isimsiz, 1984

\subsubsection{Ahmet Öner Gezgin ( 1948 - )}

Fotoğrafta kendine özgü ve zengin bir anlatım diline sahip sanatçılardan Ahmet Öner Gezgin, Türkiye'de deneysel fotoğraf alanında öncü isimlerden biridir. Karanlıkoda dönüştürme yöntemleri, fotomontaj gibi pek çok teknikle üretimler yapan sanatçı, nesnel gerçekliği yansıtan betimlemeye dayalı fotoğrafi anlayışını kıran ve deneysel yaklaşımları destekleyen sanat üslubunun oluşmasındaki en önemli etkinin Dadaist sanatçı ManRay'in manifestosu olduğunu ifade eder (Gezgin,1995). Gezgin yıllara dayanan sanat anlayışını şu ifadelerle açıklamaktadır: 
"80'li yılların Türkiye'sinde fotoğrafçı fırsatçılığı bağlamında betimlemeye dayalı kalıpların yıkılmasında önemli rol oynayan, dönemin kurama ve uygulamaya dönük altyapısının oluşmasına katkı sağlayan ve ivme kazandıran birisi olarak; yaşanılan nesnel gerçeklik içinde 'an'ı fotograflamak yerine izlemeyi; zaman içinde düş gücünden, bir düş ya da bilinçaltı bir dürtüden kaynaklanan şeylerin imgelerini birleştirerek, öteki gerçeklikle yüz yüze gelmenin akışkan bir yolu olarak, tıpkı tiyatroda olduğu gibi, kendi öznel gerçekliğimi yaratmayı ve çalışmalarıma yansıtmayı ilke edindim." (URL-10)

Türkiye'de geleneksel fotoğrafinin yüzeysel görsellik ile düz anlamsal fotoğrafik göstergelerini sanata göndermede yeterli bulmayan sanatçı, bu döngüyü kıran ilk deneysel yaklaşımların 1980'li yıllarda başlamış olmasına karşın, sosyal gerçekçi yorumlar arasında sıkışıp kalan belgesel fotoğrafi anlayışı ile deneysel fotoğrafi anlayışı arasında bugün bile derin bir ayrılık olduğunu ifade etmektedir (Gezgin,1996).

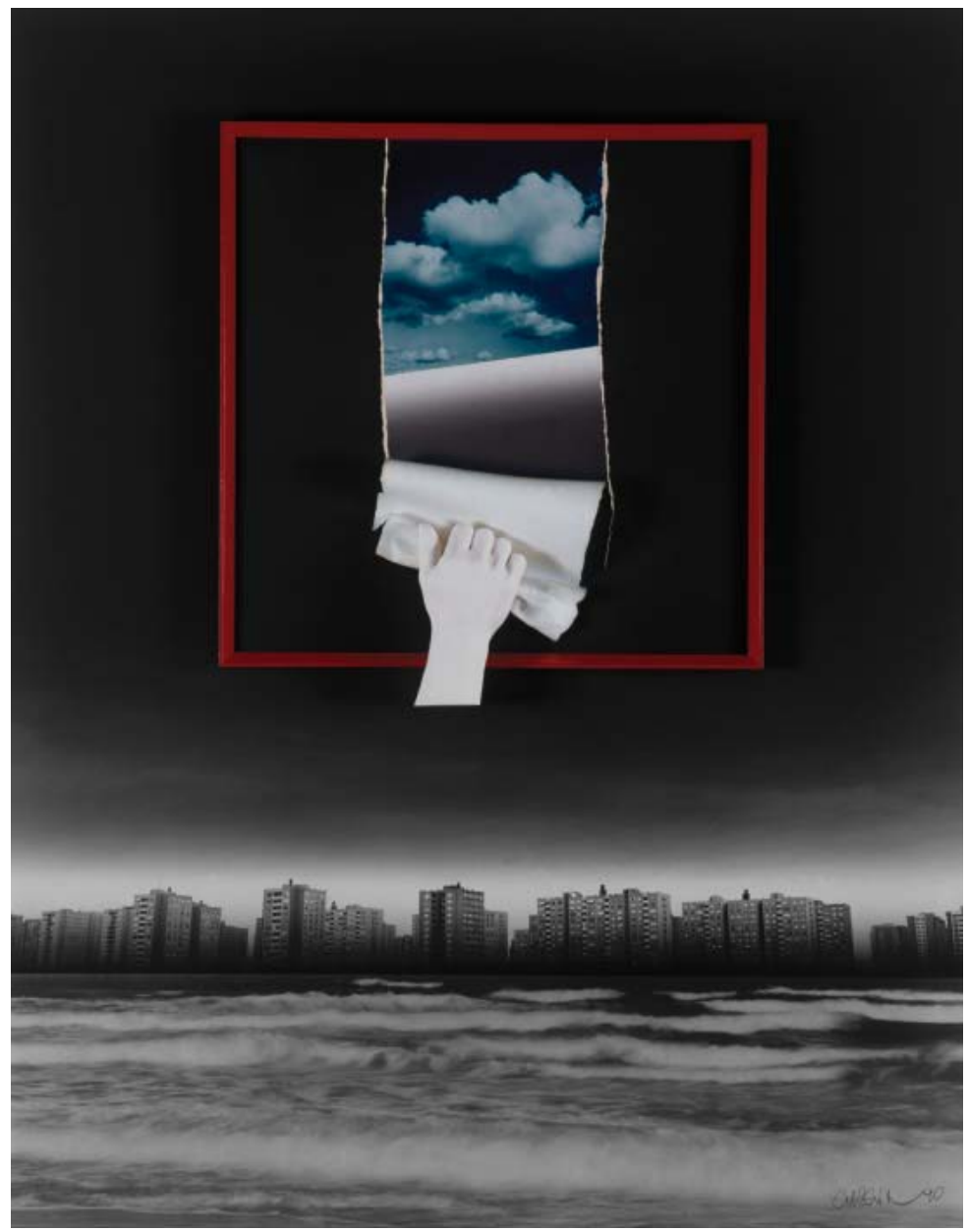

Şekil 15. Ahmet Öner Gezgin, Kırmızı Çerçeve, Karışık Teknik, 132×104cm, 1990

Üniversite eğitiminin ardında 1972 yılında devlet burslusu olarak Almanya Kassel Üniversitesin'de "deneysel fotoğraf" ve "grafik tasarım" eğitimi alan sanatçı; deneysel fotoğrafı "anlam kurma" amacıyla teknolojik alt yapısı olan bir araç olarak kullanır. Gezgin Fotoğrafi sınırları içine girmeyen her şeyin denendiği özgür bir ortam yaratma çabasını dışavurumda özgürlük olarak nitelendirir. (URL-4) 


\subsubsection{Ali Alışır (1978 - )}

Yeditepe Üniversitesinde Grafik eğitimi alan Ali Alışır, eğitimi süresince fotoğrafta dijital kurgu üzerine yoğunlaşmıştır. Aynı üniversitenin Grafik bölümünde ders veren sanatçı toplumsal sorunları edebiyat, sinema, sosyoloji ve felsefe gibi farklı disiplinlerin de dahil olduğu, fotoğrafta dijital müdahalelerde bulunarak ürettiği çalışmalarıyla ele alır.

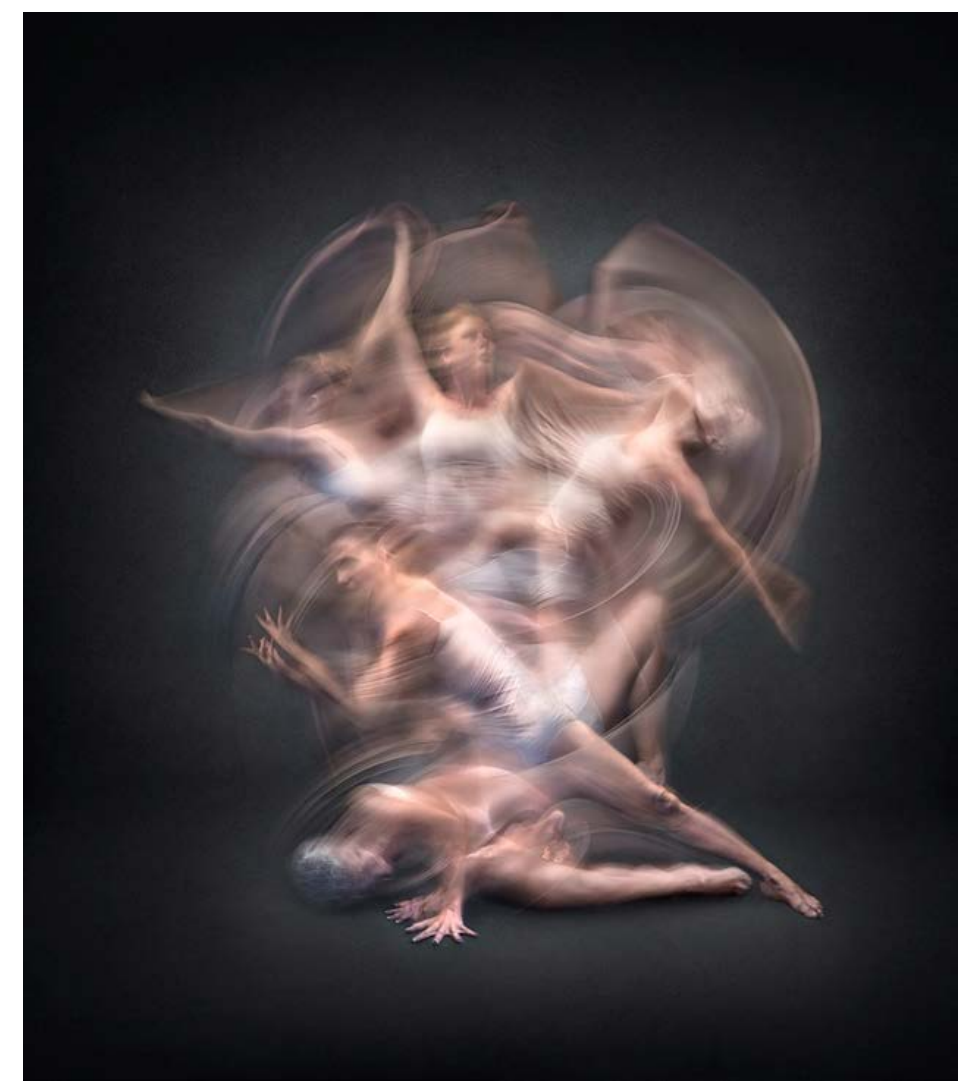

Şekil 16. Ali Alışır, Hybrid Souls \#1 - 171 x 150 cm / Unique Fineart Print - 201,2019

Uzun yıllar resim sanatıyla ilgilenen Alışır üniversite eğitiminin ardından gittiği İtalya'da fotoğrafi çalışmalarına başlamış ve hayatını bizzat etkileyen konuları sanatında işlemiştir. Fotoğraf ve resim arasında özgün bir dil yaratan sanatçı, 2009 yılından itibaren üretimlerinde "sanal" ve " gerçeklik" kavramlarını irdeler. Sanatçının bu bağlamda açtığı Sanal Bedenler, Sanal Mekanlar, Sanal Savaşlar ve Sanal Manzarlar isimli kişisel sergileri modern insanın yalnızlığını ve çaresizliğini gözler önüne sermektedir. (URL-11) 


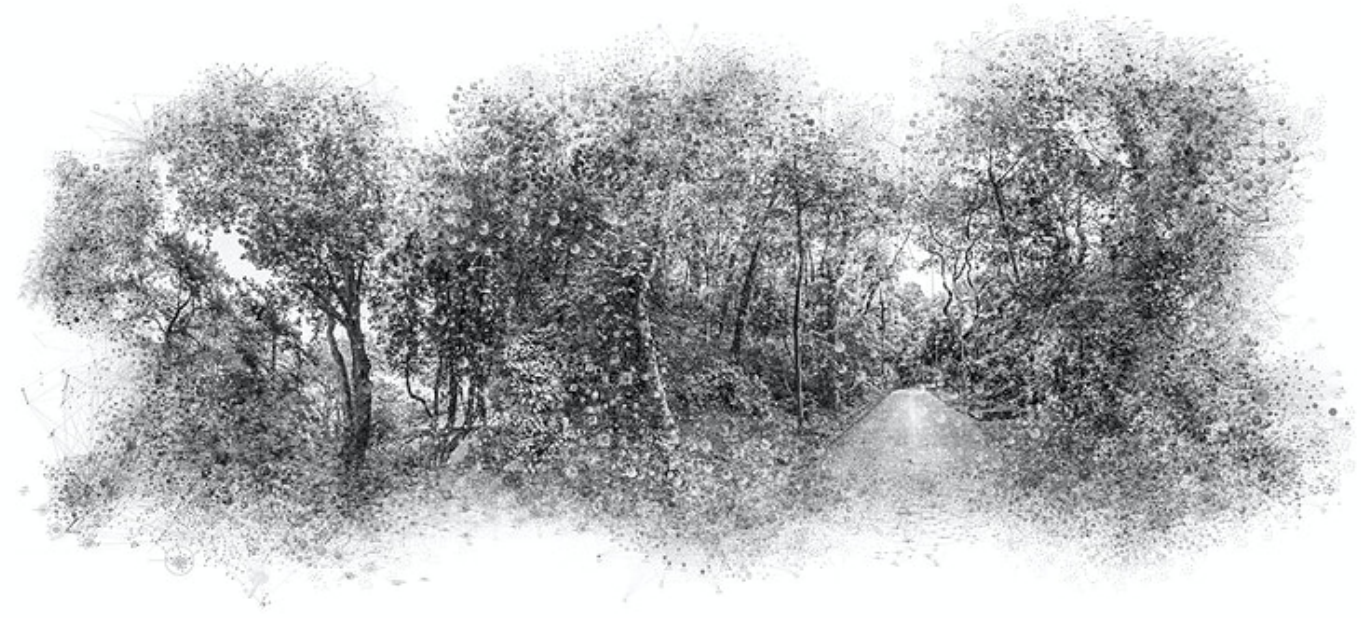

Şekil 17. Ali Alışır, Virtual Landscapes, $01-100$ x 200 cm, 2015

Teknolojinin sağladığı olanaklarla fotoğrafı resim gibi işleyen ve dönüştüren Alışır, resim ve fotoğrafın biraradalığını gösteren çalışmaları hakkında şunları ifade eder:

"Resim kökenli bir sanatçıyım, ama uzun bir süredir çağdaş fotoğraf sanatıyla ilgili çalışmalar üretiyorum. Ben ikisini birbirinden ayırmıyorum. Eğer anlatmak istediğiniz bir şeyler varsa yöntemin çok da önemli olmadığını düşünüyorum. Ben bu çalışmaları boya ile ya da kilden de üretiyor olabildirdim, ama ben ışığı tercih ettim. Bir nevi ışıkla resim yapıyorum". (URL-11)

Sanat yaşantısındaki özgün bir üslup ve deneyin kazandığı en önemli dönemi İtalya'da yaşadığı yıllar olan sanatçı, çok fazla üretimin olduğu günümüz sanatında başarının sırrının özgün bir ifade dili yaratmaktan geçtiğini belirtir.

\subsubsection{Murat Germen (1965 - )}

Fotoğraf mimarlık yeni medya ve sanat konularında pek çok basılı yayına sahip sanatçı aynı zamanda eğitimci ve arşivci olan Murat Germen, fotoğrafı dijital imkanlarla dönüştüren fotomontaj üretimler yapmaktadır. Sanatçı "Sayısal Sanat" olarak nitelendirdiği üslubunun mimarlık eğitimi sırasında analogdan dijitale geçişin temellerinin atıldığı dönemde şekillendiğini ifade eder. (URL-8)

Dijital ortamda sayısal görüntü, bilgisayar modellemeleri ve çizimleri fotoğraflarıyla birlikte kurgulayan Germen; eserlerinin üretimindeki aşamaları şu ifadelerle açıklar:

"Bigisayarlarımda Photoshop dışında birçok başka yazııım da yüklü. Bunların hepsi farklı amaçlara hizmet ediyorlar. Bu yazılımların üretmeye muktedir olduğu sonuçları gayet iyi bildiğim için makine+lens satın alırken, çekimleri yaparken ona göre kararlar veriyorum, ki daha sonra eksik bir şey kalmasın ve pişman olmayayım." (M. Germen, kişisel iletişim, Ağustos 2020) 


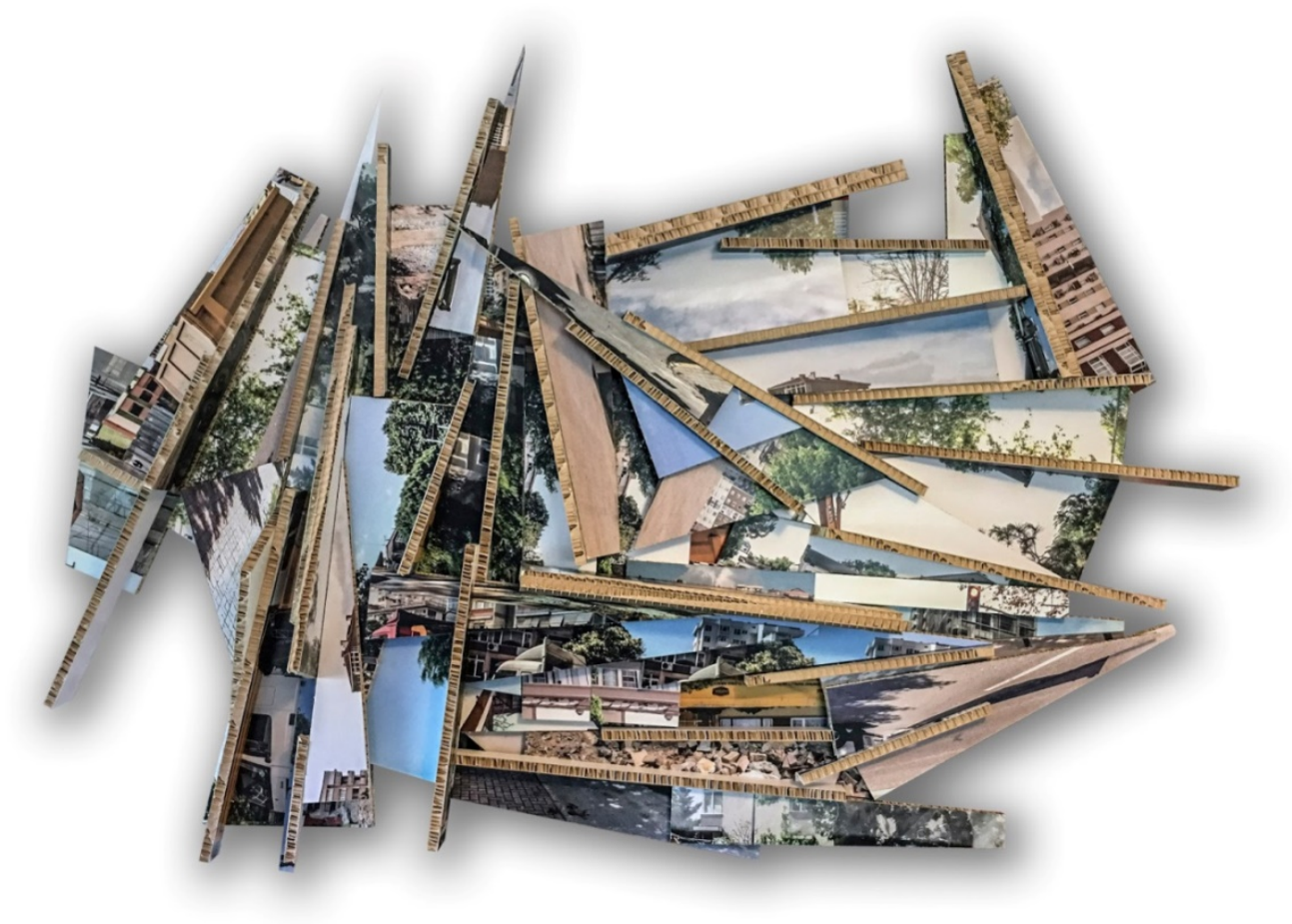

Şekil 18. Dipsiz-Namekan, $201780 \times 114 \times 14 \mathrm{~cm}$, Panele sıvanmış folyo baskılardan oluşan katmanlı fotomontaj

Sanatçı, mimarlık eğitiminden dolayı üretimlerinin kavramsal boyutunda ağırlıklı olarak mimari yapılar ve şehirlerdeki dönüşüm konularını ele alır. Mekana duyarlı ve kentsel dönüşüm konulu üretimlerinde aynı zamanda mekanı zaman kavramıyla da ilişkilendiren Germen; üretimlerinde kullanmış olduğu tekniğin kavramsal anlatıma gerekli zemini sağlaması gerektiğini düşünmektir. (URL-5) Çalışmalarında gerçeküstücülük ve fotoğraf estetiğini harmanlayan Germen:

"Gençliğimden beri, görsel tasvir ve olgusal / kurgusal bilgi aktarımı söz konusu olduğunda hep "farklı"nın, marjinalin peşinde oldum; bana daha zengin bir hayat sundukları için... Algı organlarım olağanın dışındaki görsellik, metinsel yapılar ve seslere her zaman daha açık oldu; onları her zaman daha çabuk gördüm ve daha çabuk yakınlık hissettim. Bu yüzden gerçeküstücülük ile tanışmam çok gecikmedi; bu tanışıklğı ise lise yıllarımda sırasıyla Maurits Cornelius Escher, René Magritte, Salvador Dali, Joan Miró gibi çok tipik isimler üzerinden edindim..." ifadelerini kullanır. (URL-3) 

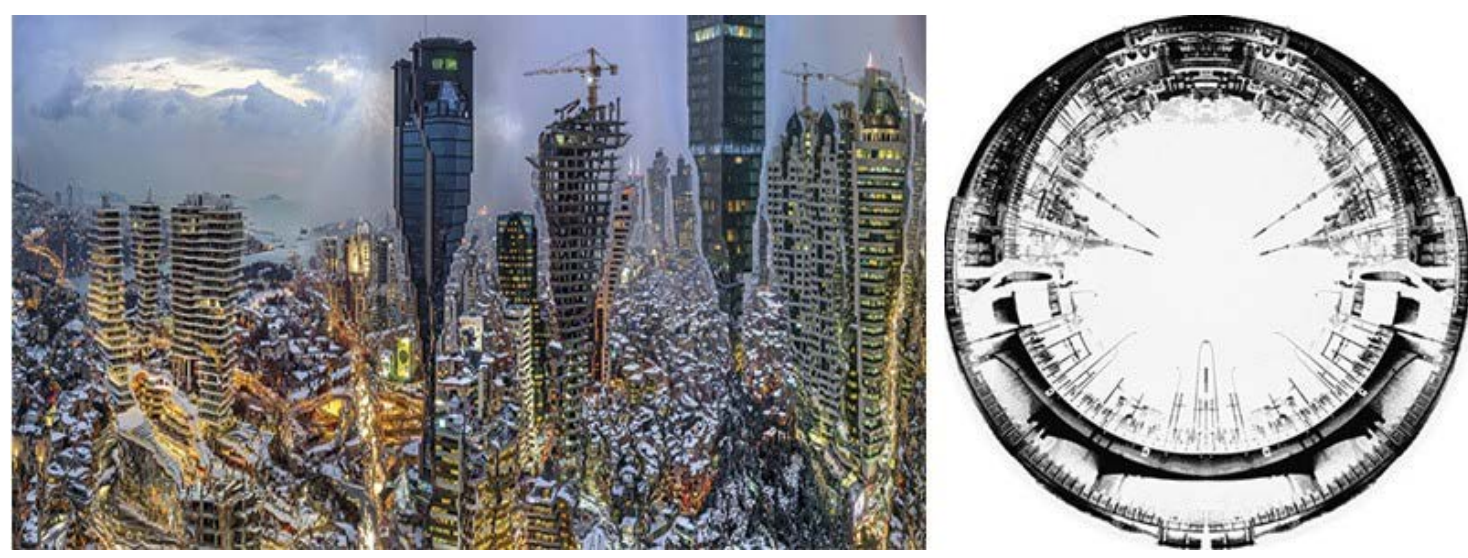

Şekil 19. Murat Germen, Muta-morfoz serisi, İstanbul, Zincirlikuyu \#01, 2013,Galata, 2007

\subsubsection{Orhan Cem Çetin (1960 - )}

1960 yılında İstanbul'da Doğan Çetin, Boğaziçi Üniversitesi Psikoloji Bölümünde almış olduğu lisans eğitiminin ardından, İstanbul Bilgi Üniversitesi Görsel İletişim Tasarım Bölümünde yüksek lisans eğitimini tamamlamıştır. Kendini fotoğraf alanında yetiştiren sanatçı, gençlik yıllarından günümüze kadar fotoğrafinin her alanıyla ilgili profesyonel olarak ilgilenmiştir. URL6

Sanatçı "Tanıdık Şeyler" isimli ilk sergisinden itibaren günümüze kadar geçen bu süreçte fotoğrafa alternatif yaklaşımlarıyla dikkat çeken ve farklı teknikleri özgün üslubuyla ele aldığı eserler üretmiştir. 2000'li yıllarda panoromik yapıştırmaya ağırlık verdiğini ifade eden Çetin, fotomontajlarının üretim sürecinde en önemli sorunsalın teknolojik ilerlemeyle birlikte gelişen manipülasyon olanaklarındaki çeşitlilik olduğunu belirtir.

Üniversitelerde fotoğraf ve video dersleri veren sanatçı günümüzdeki teknolojik ilerleme fotoğraf ve fotoğrafideki deneysel yaklaşımlar arasındaki ilişkiyi şu sözlerle ifade eder:

"Bizim kuşak karanlık odadan aydınlık odaya geçişi yaşadı. Sayısal devrimden sonra bu alana giren gençler ise analog fotoğrafçılığı deneysel bir yöntem olarak algılıyor ve ifade olanaklarını araştırıyorlar. Oysa bizim kuşakta çoğu fotoğrafçı analog yöntemleri yüceltip sayısal platforma direnç göstermiştir. "Ya biri ya da öteki" anlayışı hakimdir. Bence bu, ufkunuzu daraltan bir yaklaşımdır. Genç kuşak çok daha önyargısız ve daha cesaretli" (URL-7) 


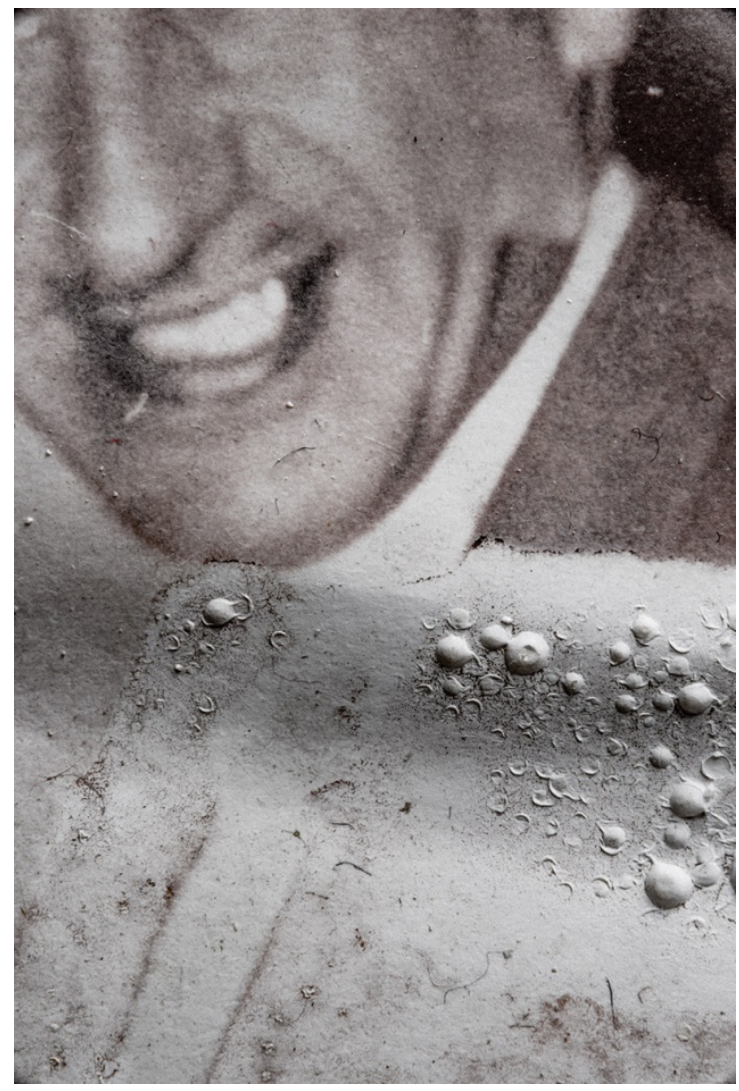

Şekil 20. Orhan Cem Çetin, Bu Adamı Tanımıyorum (Benimsin sergisinden), 2016

"Benimsin" adlı kişisel sergisinde yer alan üretimlerinde 1960'l yıllara ait aile fotoğraflara ve eskicilerden toparlamış olduğu kime ait olduğu belli olmayan fotoğraflara sayısal ortamında müdahalede bulunan sanatçı, fotoğrafların manipülasyonunda kullanmış olduğu tekniği şu ifadelerle özetler:

"Fotoğrafın gerçekliğe dair her zaman söylediği yalan bu kez barizdi. Ben de bu fotoğrafları yeni gerçekliğe yaklaştırmak üzere bir işlem yapmaya karar verdim. Tümüyle kimyasal, hatta biraz da tehlikeli bir işlem. Görüntüyü oluşturan ve "duyarkat" adı verilen ince jelatin katmanın, genleşerek alttaki kartondan ayrılmasını sağlayan bir çözeltinin içinde bekletildiler. Kimi kabardı, kimi dağııı gitti, kimi buruştu. Hepsi farkı tepki verdiler, farklı biçimlerde yıprandılar. Daha sonra da fotoğrafları çekildi. Objelerin göründügü fotoğraflarda ise ayrıntıların, özellikle toz taneciklerinin, ipliciklerin ne kadar çok olduğunun görünmesi önemliydi. Makro objektifler ile büyütme elde ettikten sonra "focus stacking" (netlik yığılması) adı verilen bir yöntem kullandım." (URL-7) 


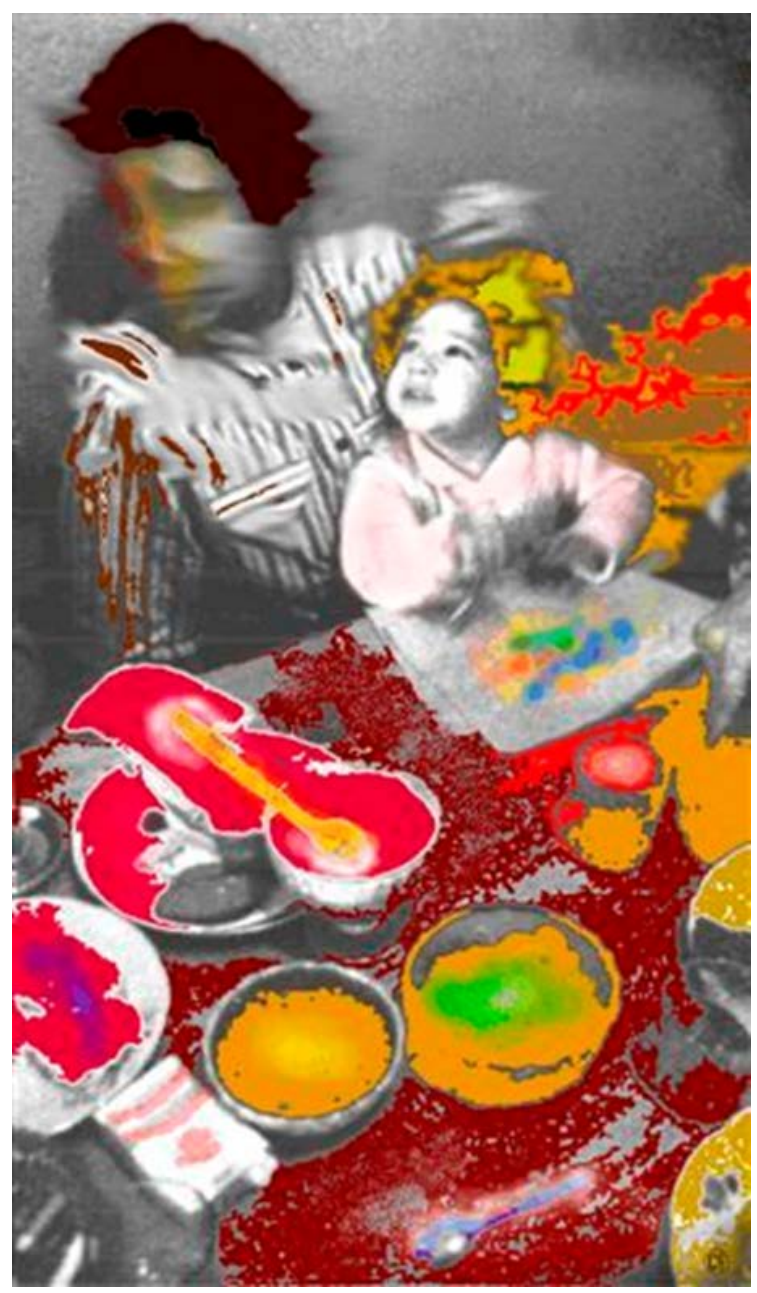

Şekil 21. Orhan Cem Çetin, Kahvaltı (Dünden Sonra" sergisinde Renk'Arnasyon" Serisinden), 1993

Fotoğraf editörlüğü ve çevirmenlikten fotoğraf yazarlığına kadar fotoğrafın pek çok alanıyla ilgili çalışmalar yapan Çetin, birçok sanatçıyla birlikte ortak çalışmalar yürütmüş; sergi ve performanslarında disiplinlerarası, kavramsal ve yenilikçi tavrını eserlerine yansıtmıştır. Sanatçı "Hücum ve Ricat" isimli sergide, buz kütlelerinin içine hapsettiği çeşitli nesneler aracılığıyla organik ve mineral aklın ilişkisini ortaya koymayı denediği makro çekimleri, Murat Germen'in üç boyuta uzanan çok katmanlı yapıtları ile beraber sergilemiş; boyutsuzluk, ölçek ve düzen kavramlarına vurgu yapmıştır. 


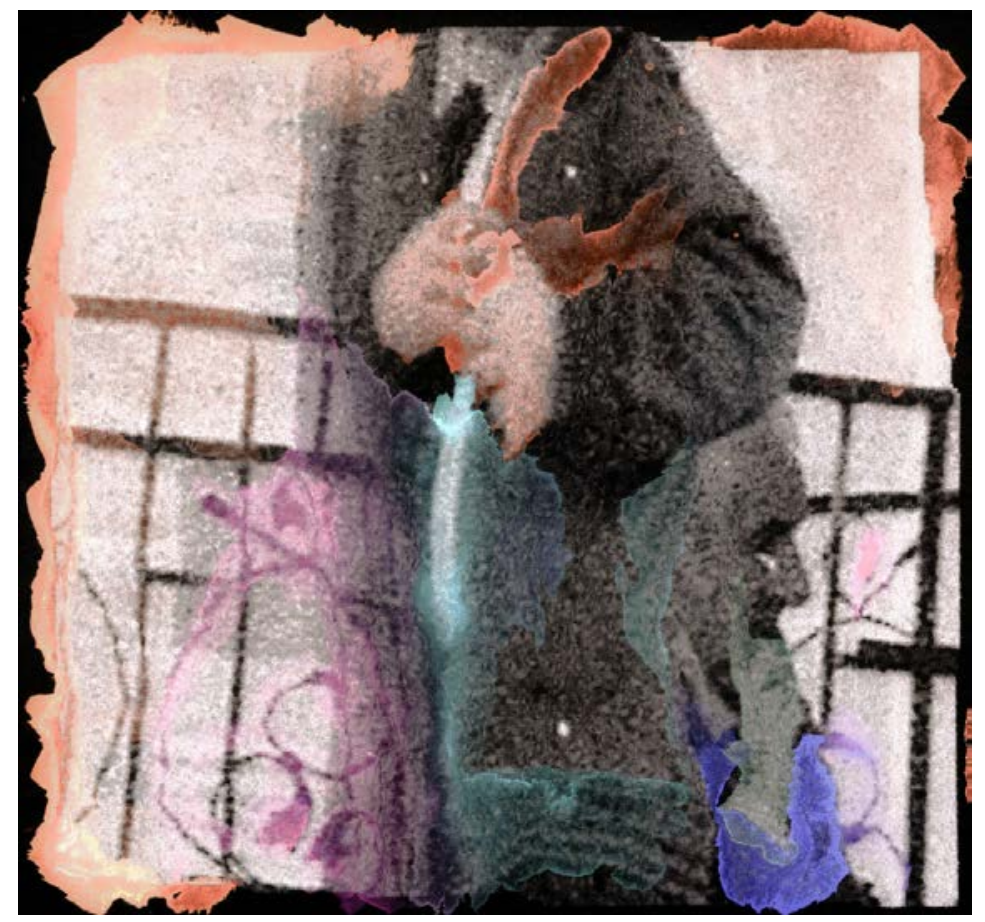

Şekil 22. Orhan Cem Çetin, Tedbir (Gümüş, Gezegen serisinden), 2014

\section{Sonuç}

20. yüzyılın toplumsal karmaşası sanat ortamını da etkilemiş ve sanatçıların farklı teknikler geliştirmelerine olanak tanımıştır. Bu dönemde fotoğraf, gerçekliği aktardığı inancıyla propaganda amaçlı sanatçıların eserlerinde sıklıkla yer almış, fotoğraf temelli teknik olan fotomontajlar metne olan gereksinimi azaltmaları ve mesaj aktarımında etkili olmaları nedeniyle Dada ve Konstrüktivizm akımı sanatçılarının en çok kullandığı ifade biçimi olmuştur.

Tarihsel süreç içinde tartışılan, fotoğrafın sanat sınırları içine girip girmeyeceği ve 'fotoğrafçı sanatçı mıdır?' sorusuna, fotoğrafın ortaya çıkış tarihi ile başlayan ve bu süreci takiben fotoğrafta kurgusal anlatım dilinin ortaya çıkması arasındaki bu zaman dilimi açıklık getirmektedir. Fotoğraf, icadının ilk yıllarında teknik odaklı ve ressamlara yardımcı bir unsur olarak sanata dahil olmuş, zaman içinde sanatçılar tarafından toplumsal belleği şekillendirme, tanıklık etme gibi özelliklerine estetik unsurların da dahil edilmesiyle zenginleştirilerek farklı sanat disiplinlerinde de kullanım alanı bulmuştur.

Fotomontaj tekniği, hem karanlık oda süreçleriyle hem de yansıtmacı geleneğin dışında renk, doku, detay çekimleriyle veya bu tekniklerin bir arada kullanılmasıyla farklı bir yere konumlanmıştır. Bu sebeple birçok sanatçı geleneksel fotoğraf anlayışının dışında fotoğrafı, kurgularında bir araç olarak kullanmış ve deneysel üretimler yapmışlardır.

Türk Sanatında 2000'li yıllarda üretimler yapan sanatçıların incelendiği bu araştırma makalesinde, sanatçıların disiplinlerarası yaklaşımlar sergiledikleri görülmüştür. Sanatçılar fotoğrafı tek başına kullanmalarını ötesinde kes-yapıştır, elle renklendirme, dijital boyama ve dijital kolajlar ile fotomontajlar oluşturmuşlardır. 
Sanatçıların ifadelerinde yaptıkları çalışmaların gruplandırmasında fotomontaj kelimesini kullanmayı çok tercih etmedikleri görülmüştür. Sanatçılar için fotomontaj kullandıkları yöntemlerden sadece bir tanesi olarak kabul edilmektedir. Sanatçıların uygulamalarında kendilerini sadece tek bir yöntem ile sınırlamak istemedikleri ve yaptıkları çalışmaları daha çok deneysel fotoğraf başlığı altında değerlendirdikleri tespit edilmiştir.

Batı sanatı tarihi içinde verilen örneklerde, kes yapıştır, üst üste pozlama, fiziksel boyama, dijital manipülasyonlar gibi farklı tekniklerin bir arada uygulandığı görülmüştür. Benzer bir anlayış, Türk Sanatı içindeki örneklerde de mevcuttur. Özellikle 2000'li yıllara ait olan çalışmalarda bilgisayar teknolojilerinin ilerlemesi ve sanatçıların bilgisayar programlarını daha yetkin bir şekilde kullanmaya başlaması ile birlikte pek çok sanatçının uygulamalarında bilgisayar alt yapısı ile çalışmalar yapmayı tercih ettiği görülmüştür.

\section{Kaynaklar}

Doğan İ ve KÜLAHOĞLU C. (1984). Fotoğrafın İçinde Yer Almak, Hürriyet Gösteri, Aralık 47

Ergün C. (2012). Temel sanat Eğitiminde ve Çağdaş Sanatta Kolaj-Fotomontaj.

DergiPark Sanat ve Tasarım Dergisi. s.9.Cilt 1 , Sayı 3. Syf 5 - 19.

Germen M. (2020). Murat Germen İle Kişisel İletişim. (K. Yavuz, Interviewer). 08.03.2020

Gülaçtı İ. E. (2018). Oryantalizm'in Ellerindeki Fotoğraf: Osmanlı Devleti'nin 19. Yüzyıl Fotoğrafçılığında 'Öteki'nin Mikrokozmosu Olarak Yansıması. Doi: 10.26650/artsanat.2018.10.0005

Lynton N. (1991). Modern Sanatın Öyküsü (2 b.). (S. Ö. Cevat Çapan, Çev.) İstanbul: Remzi Kitapevi. syf 140-142

Sezer I. ve Demircan Ö. (2016). Türk Fotoğrafında Yeni Bir Soluk: Deneysel/Kurgu Fotoğraf". Yedi: Sanat, Tasarım ve Bilim Dergisi. Sayı 15:41-52

Soylu R. ve Yıldırım N. (2019). Fotoğraflarında Resimsel Yaklaşımlar. Ekev Akademi Dergisi. Yıl: 23 Sayı: 77

Sözen M. ve Tanyeli U. (1994). Sanat Kavram ve Terimler Sözlüğü. 3.b., Remzi Kitapevi, s. 86

Sucuoğlu M. (2016). Man Ray, Rayogram Tekniği Ve Resim Sanatında Değişimler. Sanat ve Tasarım DergisiSayı. Cilt 6 , Sayı 1, Syf 192 - 204.

http://dergipark.gov.tr/download/article-file/275121)

Topçuoğlu N. (2000). Fotoğraf Ölmedi Fakat Tuhaf Kokuyor., 1.b., İstanbul: Yapıkredi Yayınları, s.117.

Yılmaz M. (2013). Modernden Postmoderne Sanat. Ankara: Ütopya Yayınları San

\section{Internet Kaynakları}

URL-1, (2017). https://tr.scribd.com/document/23283244/kolaj-tarihinegiriş-introduct, (accessed in: 10.12.2017), (In Turkish).

URL-2, (2020). https://www.ahmetonergezgin.com.tr/fotomontaj-1/ (accessed in: 10.09.2020), (In Turkish).

URL-3, (2020). https://muratgermen.wordpress.com/tag/orhan-cem-cetin/, (accessed in: 11.09.2020), (In Turkish).

URL-4, (2020).https://www.aydinlik.com.tr/ahmet-oner-gezgin-deneysel-fotografin profesoru-205731\#4, (accessed in: 17.04.2020), (In Turkish). 
URL-5, (2020). https://t24.com.tr/k24/yazi/murat-germen-fotograf,2503, (accessed in: 26.12.2019), (In Turkish).

URL-6, (2021). http://www.orhancemcetin.com/, (accessed in: 08.03.2020), (In Turkish).

URL-7, (2021), https://haberler. boun.edu.tr/tr/haber/fotograf-ve-metin-birbirinin-gerceklikve\% 20anlam\% 20-ihtiyacini-giderir. (accessed in: 26.03.2016), (In Turkish).

URL-8, (2021). https://kulturlimited.com/2018/09/14/fotografin-turlu-halleri-murat-germenkesit-retrospektif-sakip-sabanci-mardin-kent-muzesinde, (accessed in: 14.09.2018), (In Turkish).

URL-9, (2021).https://www.merriam-webster.com/dictionary/photomontage, (accessed in: 21.11.2018), (In Turkish).

URL-10, (2021). https://www.ahmetonergezgin.com.tr/, (accessed in: 20.11.2020), (In Turkish).

URL-11,(2020) https://www. murekkephaber.com/ali-alisir-bir-nevi-isikla-resimyapiyorum/4297/, (accessed in: 21.11.2020), (In Turkish).

URL-12， 2(020). http://fotografneyianlatir.blogspot.com/2009/10/hyatin-iki-yuzu. html9. (accessed in: 07.09.2020), (In Turkish).

\section{Extended Abstract}

Photomontage, which is one of the essential techniques of today's art, with the innovations provided by the digital environment, is frequently applied with classical dark room methods and experimental approaches. Photomontage, which is formed by the combination of two separate photographs in a new composition in its simplest form, is a technique applied in many Western Art Movements from Dada to Pop Art. It has found a field of application in Turkey after the 1980s.

In this study, it is aimed to examine the first application forms of the photomontage technique in the history of western art, to investigate how it gave direction to world art based on the applications, and to examine its reflections in Turkish painting art in the 2000s. The approach of the Artists who builds artwork using the photomontage method in the art environment in Turkey is the subject of this study.

The research article has been limited to Turkish artists who have used the photomontage technique in their works since the 2000s. The photomontage applications of the artists, Şahin Kaygun, Ahmet Öner Gezgin, Ali Alisir, Murat Germen, Orhan Cem Çetin, who are the main subject of the research and who perform applications with the photomontage technique in Turkey in the 2000s, are presented with examples.

The data generating this research were carried out by scanning the visual and written sources of different disciplines. In addition to the literature review, visual examples related to the subject were researched, the artists involved in the research were contacted, and a visual documentation was recorded with the works of the artists. During the research, the theoretical data obtained from the catalogs of the private art gallery, the libraries of the universities and electronic resources were scanned. Interviews were held with the artists selected as examples in the research. The obtained data is presented in the study. 
As an artistic form of the use of photomontage technique, which has a wide usage area, changing and developing social order and needs, which we see unlimited application examples today, based on ancient history than the application examples in Western Art.

Photography became an area of interest for non-Muslims within the Ottoman borders and for Western travelers who approached the life of the Orient from an exotic and imaginary point of view. It was a process that started with the Republican period that photography found an area of application in the visual communication system in Turkey and became a communication tool that could meet the needs of contemporary society.

Şahin Kaygun intervened in the Polaroid photographs she took with a brush and paint. The artist has many art works in which he transforms photographs into paintings. Ahmet Öner Gezgin included experimental way of searching in his works. He created different compositions apart from the classical description. Ali Alisir, who processes and transforms photography like a painting with the opportunities provided by technology, works to show the unity of painting and photography.

Murat Germen fictionalizes photomontages in which she transforms photographs with digital opportunities. He carries out conceptual studies by using computer technology in his compositions where architectural structures are dominant. Orhan Cem Çetin creates panoramic images in his experimental photography works. He uses computers and videos in his work. He uses computers and videos in his works.

The photomontage technique is positioned in a different place, both with dark room processes and outside the reflective tradition, with color, texture, extreme close ups or the use of these techniques together. For this reason, many artists have used photography as a tool in their fictions and made experimental productions, apart from the traditional understanding of photography.

In this research article, which was analyzed by the artists who made productions in Turkish Art in the 2000s, it was seen that the artists exhibited interdisciplinary approaches. Beyond using the photo solely, they created photomontages with cut-paste, hand coloring, digital painting and digital collages.

As a result of the research, it has been detected that the intervention to the photographic image is carried out with the possibilities of the digital environment today. It has been seen that the artists who made photomontage works in Turkey in the 2000s used photomontage with various techniques in a multidisciplinary approach.

In the given examples in the history of Western art, it has been seen that different techniques such as cut and paste, overlapping image, physical painting, and digital manipulations are applied together. A similar understanding is also present in the examples in Turkish Art. Especially in the artworks of the 2000s, with the advancement of computer technologies and the artists' starting to use computer programs more competently, it has been seen that many artists prefer to work with computer infrastructure in their applications. 